Article

\title{
Extra-Framework Content in Sodalite-Group Minerals: Complexity and New Aspects of Its Study Using Infrared and Raman Spectroscopy
}

\author{
Nikita V. Chukanov ${ }^{1,2, *}$, Marina F. Vigasina ${ }^{2}$, Natalia V. Zubkova ${ }^{2}$, Igor V. Pekov ${ }^{2,3}$, \\ Christof Schäfer ${ }^{4}$, Anatoly V. Kasatkin ${ }^{5}$, Vasiliy O. Yapaskurt ${ }^{2}$ and Dmitry Yu. Pushcharovsky ${ }^{2}$ \\ 1 Institute of Problems of Chemical Physics, Russian Academy of Sciences, Chernogolovka, \\ 142432 Moscow, Russia \\ 2 Faculty of Geology, Moscow State University, Vorobievy Gory, 119991 Moscow, Russia; \\ vigasina55@mail.ru (M.F.V.); n.v.zubkova@gmail.com (N.V.Z.); igorpekov@mail.ru (I.V.P.); \\ yvo72@geol.msu.ru (V.O.Y.); dmitp@geol.msu.ru (D.Y.P.) \\ 3 Vernadsky Institute of Geochemistry and Analytical Chemistry, Russian Academy of Sciences, \\ Kosygina str. 19, 119991 Moscow, Russia \\ 4 Gustav Stresemann-Strasse 34, 74257 Untereisesheim, Germany; mspech612@gmail.com \\ 5 Fersman Mineralogical Museum of the Russian Academy of Sciences, Leninsky Prospekt, 18-2, \\ 119071 Moscow, Russia; kasatkin@inbox.ru \\ * Correspondence: nikchukanov@yandex.ru; Tel.: +7-4965221556
}

Received: 23 March 2020; Accepted: 14 April 2020; Published: 17 April 2020

\begin{abstract}
Nine samples of carbonate-free sodalite-group minerals, including those with abnormally high contents of polysulfide groups, fluoride anion and carbon dioxide molecules as well as synthetic fluoraluminate sodalite-type compound $\mathrm{Na}_{8}\left(\mathrm{Si}_{7} \mathrm{Al}_{5} \mathrm{O}_{24}\right)\left(\mathrm{AlF}_{6}\right)^{3-} \cdot 5 \mathrm{H}_{2} \mathrm{O}$, have been studied by means of electron microprobe analyses, infrared and Raman spectroscopy; the $\mathrm{CO}_{2}$ content was determined using the selective sorption of gaseous ignition products. This article describes a semi-quantitative method for estimating the content of carbon dioxide molecules in these minerals, based on IR spectroscopy data. The data obtained demonstrate the existence of a sulfide sodalite-group mineral with the idealized formula $\mathrm{Na}_{7}\left(\mathrm{Si}_{6} \mathrm{Al}_{6} \mathrm{O}_{24}\right)\left(\mathrm{S}_{3}{ }^{-}\right) \cdot \mathrm{H}_{2} \mathrm{O}$, which differs significantly from the formula $\mathrm{Na}_{6} \mathrm{Ca}_{2}\left(\mathrm{Si}_{6} \mathrm{Al}_{6} \mathrm{O}_{24}\right) \mathrm{S}^{2-}{ }_{2}$ accepted for lazurite. According to single-crystal $\mathrm{X}$-ray structural analysis, in the F-rich sodalite-group mineral from the Eifel paleovolcanic region, Germany with the idealized formula $\mathrm{Na}_{7}\left(\mathrm{Si}_{6} \mathrm{Al}_{6} \mathrm{O}_{24}\right) \mathrm{F}^{-} \cdot n \mathrm{H}_{2} \mathrm{O}$ fluorine occurs as an isolated $\mathrm{F}^{-}$anion, unlike synthetic F-rich sodalite-type compounds.
\end{abstract}

Keywords: mineral; sodalite group; extra-framework species; infrared spectroscopy; Raman spectroscopy; crystal structure; polysulfide radical anion

\section{Introduction}

Natural aluminosilicates belonging to the sodalite group are feldspathoids whose crystal structures are based on the tetrahedral framework $\left(\mathrm{Al}_{x} \mathrm{Si}_{1-x} \mathrm{O}_{2}\right)^{\mathrm{x}-}$ with large cavities (so-called $\beta$-cages) hosting large cations $\left(\mathrm{Na}^{+}, \mathrm{K}^{+}, \mathrm{Ca}^{2+}\right)$, additional anions $\left(\mathrm{Cl}^{-}, \mathrm{F}^{-}, \mathrm{SO}_{4}{ }^{2-}, \mathrm{S}^{2-}, \mathrm{S}_{3}{ }^{-}\right.$, etc. $)$and neutral molecules $\left(\mathrm{H}_{2} \mathrm{O}, \mathrm{CO}_{2}\right)$ [1-11]. Sodalite-type compounds with different additional anions $\left(\mathrm{CO}_{3}{ }^{-}, \mathrm{HCOO}^{-}, \mathrm{AlF}_{6}{ }^{3-}\right.$, $\mathrm{OH}^{-}$) have been synthesized [12-16].

Vibrational (infrared and Raman) spectroscopy has proven to be an effective tool with which various anionic and neutral extra-framework groups in minerals of the sodalite group can be identified. However, a number of unresolved problems remain related to the quantitative determination of the relative contents of various groups containing $\mathrm{C}, \mathrm{S}$, and F, the limits of carbon dioxide contents, the 
writing of chemical formulae for members of the sodalite group with high sulfur and fluorine contents, as well as the present-day problem with the status of lazurite in the nomenclature of minerals. In this work, a combination of infrared and Raman spectroscopy was applied to the study of extra-framework anionic and neutral groups in nine samples of sodalite-group minerals with contrastingly different chemical compositions, including samples with abnormally high contents of polysulfide groups, fluoride anion and carbon dioxide molecules. In addition, this paper describes a semi-quantitative method for estimating the content of $\mathrm{CO}_{2}$ molecules in these minerals, based on IR spectroscopy data.

\section{Materials and Methods}

The samples investigated in this work are as follows.

Sample 1 is blue sodalite, forming grains up to $3 \mathrm{~cm}$ across in a cancrinite-sodalite pegmatite uncovered at the western slope of Mount Kobelikha, in the bench bottom of the open pit situated in the Vishnevogorskiy syenite-miaskite complex, South Urals, Russia. Associated minerals are potassium feldspar, cancrinite, annite, muscovite, different zeolites, as well as accessory zircon, thorite, ilmenite, columbite-(Fe), Nb-bearing rutile, a pyrochlore-group mineral, various sulfides etc. [17].

Sample 2 is gray nosean forming crystals up to $0.5 \mathrm{~cm}$ across and twins on (111) up to $1 \mathrm{~cm}$ long in cavities of nosean sanidinite in the In den Dellen (Zieglowski) pumice quarry, $1.5 \mathrm{~km} \mathrm{NE} \mathrm{of} \mathrm{Mendig,}$ Laach Lake (Laacher See) paleovolcano, Eifel region, Rhineland-Palatinate, Germany. Metasomatic nosean sanidinites of the Laach Lake area are derivatives of foyaite magmas which are comagmatic with nosean-cancrinite-nepheline syenites [18-22]. Associated minerals are sanidine, augite, annite, and zircon.

Sample 3 is blue rock-forming $\mathrm{SO}_{4}$-bearing triclinic lazurite (intermediate member of the haüyne-lazurite solid-solution series) from the Malobystrinskoe lazurite deposit, Baikal Lake area, Siberia, Russia [23]. Associated minerals are calcite, diopside, pyrite, fluorapatite, and phlogopite. The sample was kindly provided by A.N. Sapozhnikov.

Sample 4 is lilac haüyne forming imperfect crystals up to $0.4 \mathrm{~cm}$ in cavities of a metasomatic rock composed of haüyne, calcite and phlogopite from the Tultuy lazurite deposit, Baikal Lake area, Siberia, Russia.

Sample 5 is light blue (with a greenish tint) rock-forming haüyne from the Malobystrinskoe lazurite deposit. Associated minerals are dolomite and diopside.

Sample 6 (Figure 1) comes from the collection of Anatoly V. Kasatkin (catalogue number 569L). It originates from the Malobystrinskoe lazurite deposit and is a fragment of lazurite-rich metasomatic rock. $\mathrm{CO}_{2}$-rich, $\mathrm{SO}_{4}$-bearing lazurite (an intermediate member of the haüyne-lazurite solid-solution series) occurs there as bright blue massive aggregates up to $3.5 \mathrm{~cm} \times 2 \mathrm{~cm}$. Other associated minerals are diopside, calcite, dolomite, anhydrite, and phlogopite.

Sample 7 is a large $(2 \mathrm{~cm} \times 3 \mathrm{~cm} \times 4 \mathrm{~cm})$ deep blue twin on (111) of sulfide-rich lazurite from calcite marble (Figure 2). The sample originates from the Sar-e Sang lazurite deposit, Badakhshan, Afghanistan, which is the type locality of lazurite.

Sample 8 is lazurite forming a deep blue outer zone of a rhombic dodecahedral crystal $2 \mathrm{~cm}$ across from calcite marble (Figure 3). The inner zone of the crystal is composed of gray haüyne. The sample originates from the Sar-e Sang lazurite deposit.

Sample 9 is an F-rich sodalite-group mineral forming yellowish twins on (111) up to $1 \mathrm{~mm}$ long in the cavities of nepheline- and biotite-bearing trachitoid sanidinite from the In den Dellen (Zieglowski) pumice quarry (Figure 4).

Sample 10 (used for comparison) is a synthetic F-rich sodalite-type compound $\mathrm{Na}_{7.38}\left(\mathrm{Si}_{6.74} \mathrm{Al}_{5.26} \mathrm{O}_{24}\right)\left(\mathrm{AlF}_{6}\right)_{0.70} \cdot 4.88 \mathrm{H}_{2} \mathrm{O}$ synthesized hydrothermally $\left(\right.$ at $\mathrm{T}=650{ }^{\circ} \mathrm{C}, P=2 \mathrm{kBar}$ ) in a $\mathrm{Si}-\mathrm{Al}-\mathrm{Na}-\mathrm{F}-\mathrm{H}_{2} \mathrm{O}$ system [14]. The sample was kindly provided by A.R. Kotel'nikov. 


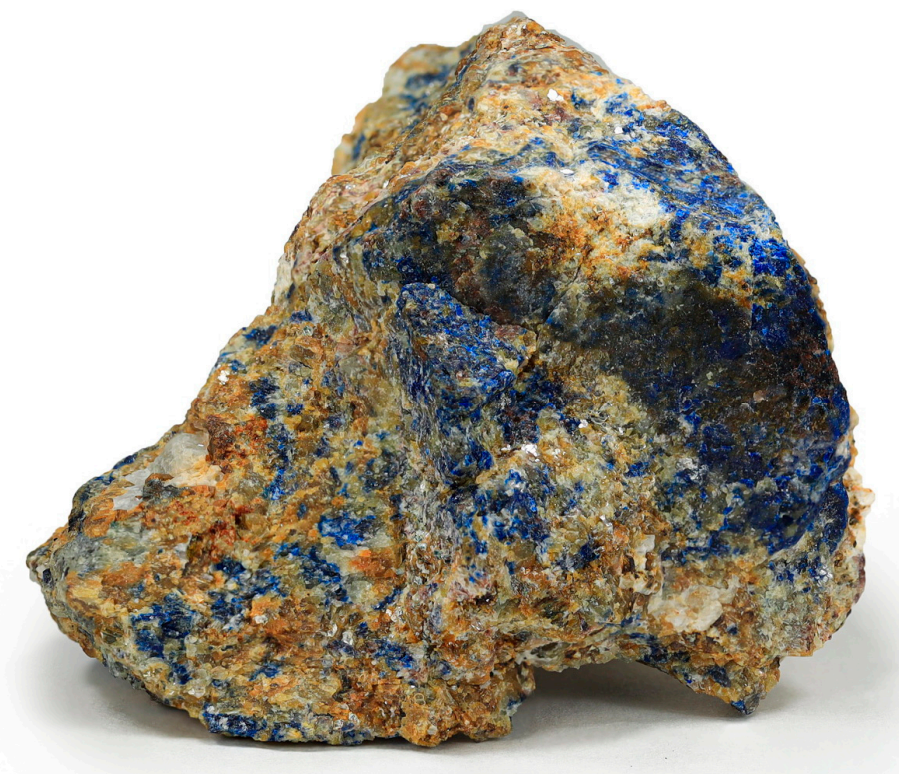

Figure 1. Bright blue $\mathrm{CO}_{2}$-rich, $\mathrm{SO}_{4}$-bearing lazurite with orange diopside in metasomatic rock. Sample 6. Field width: $9 \mathrm{~cm}$. Photographer: Anastasia D. Kasatkina.

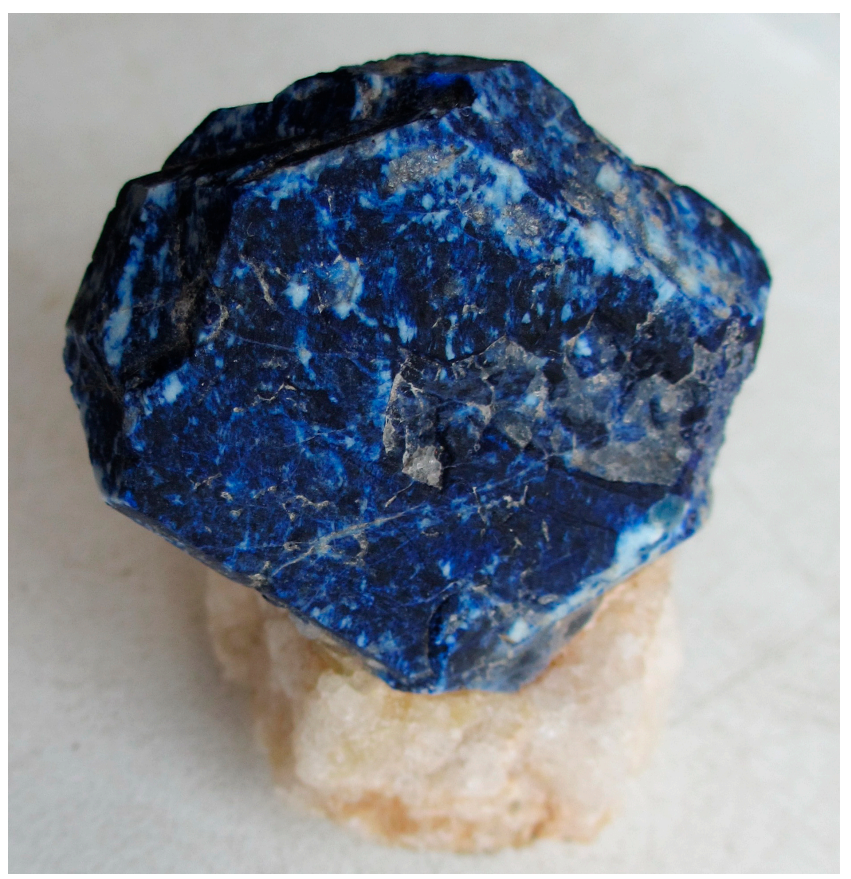

Figure 2. Twin of a deep blue sulfide-rich lazurite extracted from calcite marble (white). Sample 7. Field width: $4.5 \mathrm{~cm}$. Photographer: Nikita V. Chukanov. 


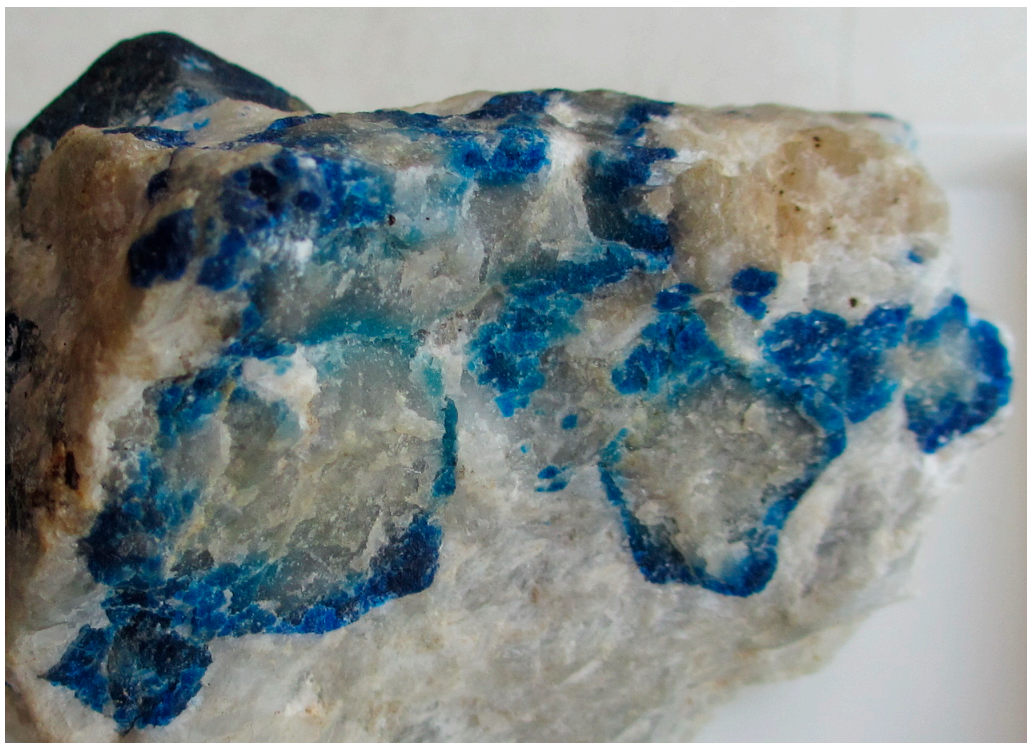

Figure 3. Zoned haüyne-lazurite crystals in calcite marble. Sample 8. Field width: $6 \mathrm{~cm}$. Photographer: Nikita V. Chukanov.

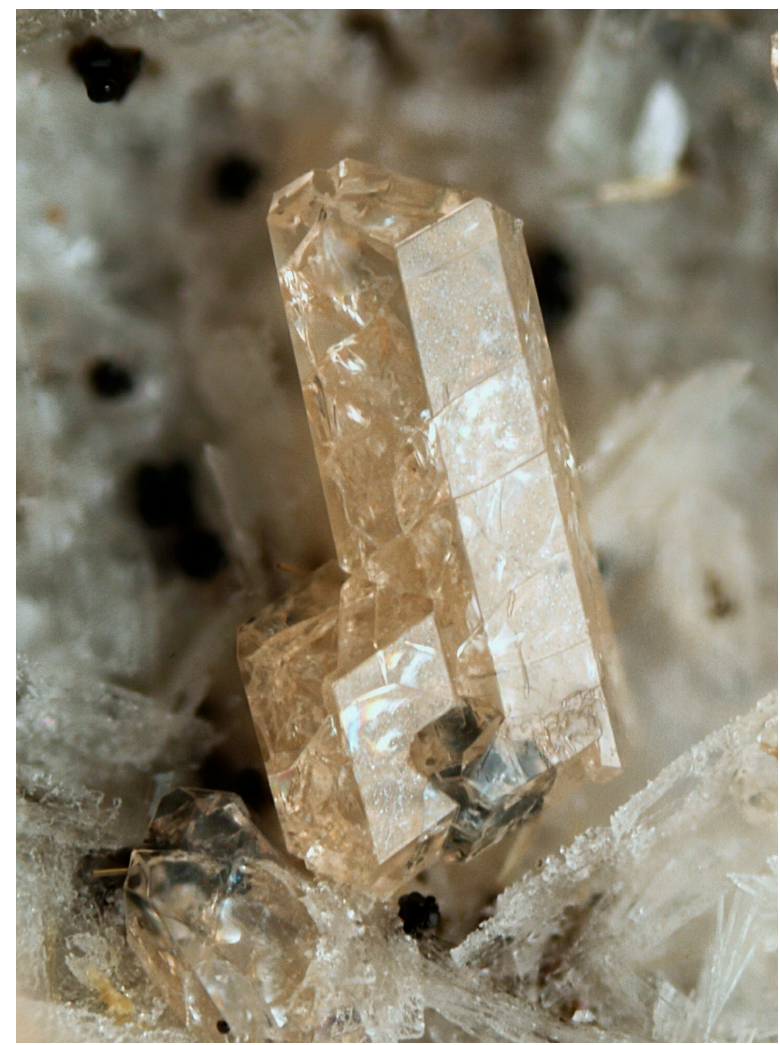

Figure 4. Twin of a F-rich sodalite-group mineral on sanidinite. Sample 9. Photographer: Marko Burkhardt. Field width: $1 \mathrm{~mm}$.

Table 1 lists the analytical methods which were used for the characterization of different samples (" + " means that the method was applied). Samples 3, 6, 7, and 9 with unusual compositional characteristics were investigated in the most detail. Samples $1,2,4,5$, and 8 played an auxiliary role and were used to obtain calibration dependence for the determination of the content of $\mathrm{CO}_{2}$ molecules from the IR spectra. Some data for Samples 1 and 10 were taken from literature sources, indicated in Table 1. 
Table 1. Techniques applied for the characterization of Samples 1 to 10.

\begin{tabular}{ccccccc}
\hline Sample No. & EDS & CO $_{2}$ Sorption & IR Spectroscopy & Raman Spectroscopy & Single-Crystal XRD \\
\hline 1 & {$[17]$} & + & + & - & - \\
\hline 2 & + & + & + & - & - \\
\hline 3 & + & + & + & + & - \\
\hline 4 & + & + & + & - & - \\
\hline 5 & + & + & + & + & - \\
\hline 6 & + & + & + & + & - \\
\hline 7 & + & + & + & - & + \\
\hline 8 & + & + & + & + & - \\
\hline 9 & + & - & + & + & \\
\hline 10 & {$[14]$} & - & + & & \\
\hline
\end{tabular}

Electron microprobe analyses (three spot analyses for each sample) were carried out using a Tescan VEGA-II XMU electronic microscope (EDS mode, $20 \mathrm{kV}, 400$ pA). Data reduction was carried out by means of a modified INCA Energy 450 software package. The size of the electron beam was $157-180 \mathrm{~nm}$. The beam was rastered on an area $20 \mu \mathrm{m} \times 20 \mu \mathrm{m}$ in order to minimize sample damage. The time of data acquisition was $50 \mathrm{~s}$. The sample-to-detector distance was $25 \mathrm{~mm}$. The standards used are: albite for $\mathrm{Na}$ and $\mathrm{Si}$, sanidine for $\mathrm{K}$, wollastonite for $\mathrm{Ca}, \mathrm{Al}_{2} \mathrm{O}_{3}$ for $\mathrm{Al}, \mathrm{BaSO}_{4}$ for $\mathrm{S}, \mathrm{CaF}_{2}$ for $\mathrm{F}$, and $\mathrm{NaCl}$ for $\mathrm{Cl}$.

The content of fluorine in the F-rich Sample 9 was determined as the mean of 11 spot analyses using a Jeol JSM-6480LV scanning electron microscope equipped with an INCA-Wave 500 wavelength-dispersive spectrometer (Laboratory of Analytical Techniques of High Spatial Resolution, Department of Petrology, Moscow State University), with an acceleration voltage of $20 \mathrm{kV}$, a beam current of $20 \mathrm{nA}$, and a $3 \mu \mathrm{m}$ beam diameter. $\mathrm{MgF}_{2}$ was used as a reference.

For all samples except Sample 7, $\mathrm{CO}_{2}$ was determined by the selective sorption of $\mathrm{CO}_{2}$ on an askarite sorbent (an asbestiform matter saturated by $\mathrm{NaOH}$ ) from gaseous products obtained by heating of the mineral at $1080{ }^{\circ} \mathrm{C}$ in oxygen at $1 \mathrm{~atm}$. For Sample $7, \mathrm{CO}_{2}$ and $\mathrm{H}_{2} \mathrm{O}$ were determined by gas chromatography of products of ignition in oxygen at $1200^{\circ} \mathrm{C}$ with a Vario Micro cube analyzer (Elementar GmbH, Frankfurt, Germany).

In order to obtain infrared (IR) absorption spectra, powdered samples were mixed with dried $\mathrm{KBr}$, pelletized, and analyzed using an ALPHA FTIR spectrometer (Bruker Optics) in the range $360-4000 \mathrm{~cm}^{-1}$ with a resolution of $4 \mathrm{~cm}^{-1}$ and 16 scans. An IR spectrum of an analogous pellet prepared from pure $\mathrm{KBr}$ was used as a reference. The optical densities of the bands at $2341-2346 \mathrm{~cm}^{-1}$ were measured relative to the optical density at $2500 \mathrm{~cm}^{-1}$. The optical densities of the band used as an internal standard was measured at the absorption maximum in the range $656-668 \mathrm{~cm}^{-1}$; the common tangents to the two deepest minima in the range $500-830 \mathrm{~cm}^{-1}$ were used as baselines.

Raman spectra of randomly oriented samples were obtained using an EnSpectr R532 spectrometer based on an OLYMPUS CX 41 microscope coupled with a diode laser $(\lambda=532 \mathrm{~nm})$ at room temperature. The spectra were recorded in the range from 100 to $4000 \mathrm{~cm}^{-1}$ with a diffraction grating $\left(1800 \mathrm{~g} \mathrm{~mm}^{-1}\right)$ and spectral resolution of about $6 \mathrm{~cm}^{-1}$. The output power of the laser beam was about $5 \mathrm{~mW}$. The diameter of the focal spot on the sample was less than $5 \mu \mathrm{m}$. The backscattered Raman signal was collected with a $40 \times$ objective; signal acquisition time for a single scan of the spectral range was $1 \mathrm{~s}$, and the signal was averaged over 50 scans. Crystalline silicon was used as a standard.

The single-crystal X-ray diffraction experiment was carried out for Sample 9 using Xcalibur S CCD diffractometer. The measured intensities were corrected for Lorentz, background, polarization and absorption effects. Data reduction was performed using CrysAlisPro Version 1.171.39.46 [24]. The studied sample is cubic, space group $I-43 m, a=9.05887(10) \AA, V=743.40(2) \AA^{3}$. The crystal structure of Sample 9 was obtained by direct methods and refined using the SHELX software package [25]. The structure was refined for the two-component twin with refined twin ratio 0.52:0.48. Experimental details are given in Table 2. 
Table 2. Crystal data, data collection information and structure refinement details for sample 9.

\begin{tabular}{|c|c|}
\hline Crystal sizes, $\mathrm{mm}$ & $0.07 \times 0.11 \times 0.13$ \\
\hline Temperature, $\mathrm{K}$ & 293 \\
\hline Radiation and wavelength, $\AA$ & $\operatorname{MoK} \alpha ; 0.71073$ \\
\hline $\mathrm{F}_{000}{ }^{*}$ & 461 \\
\hline Diffractometer & Xcalibur S CCD \\
\hline$\theta$ range for data collection, ${ }^{\circ}$ & $5.514-30.359$ \\
\hline$h, k, l$ ranges & $-12 \leq h \leq 12,-12 \leq k \leq 12,-12 \leq l \leq 12$ \\
\hline Reflections used in the refinement: total/with $I>2 \sigma(I)$ & $728 / 725$ \\
\hline Data reduction & CrysAlisPro Version 1.171.39.46 \\
\hline Absorption correction & multi-scan \\
\hline Refinement method & Full-matrix least-squares on $F^{2}$ \\
\hline Number of refined parameters & 21 \\
\hline Final $R$ indices (with $I>2 \sigma(I)) R 1 / \mathrm{w} R 2$ & $0.0430 / 0.1050$ \\
\hline$R$ indices (with all data) & $0.0433 / 0.1052$ \\
\hline GoF & 1.161 \\
\hline Largest diffraction peak and hole, e/ $\AA^{3}$ & 0.71 and -0.33 \\
\hline
\end{tabular}

* Calculated based on structural data.

\section{Results}

\subsection{Chemical Composition}

Chemical data for the studied sodalite-group minerals are given in Table 3. The $\mathrm{CO}_{2}$ content in Sample 9 was determined by means of IR spectroscopy (see below).

Table 3. Chemical composition of sodalite-group minerals.

\begin{tabular}{|c|c|c|c|c|c|c|c|c|c|c|}
\hline \multirow[b]{2}{*}{ Compo-nent } & \multicolumn{10}{|c|}{ Sample No. } \\
\hline & $1^{a}$ & 2 & 3 & 4 & 5 & 6 & 7 & 8 & 9 & $10^{b}$ \\
\hline $\mathrm{Na}_{2} \mathrm{O}$ & 24.97 & 16.96 & 18.60 & 18.33 & 19.02 & 20.66 & 17.88 & 18.08 & 19.00 & 21.5 \\
\hline $\mathrm{K}_{2} \mathrm{O}$ & bdl & 2.90 & bdl & 0.13 & bdl & 0.66 & 1.06 & 0.53 & 4.04 & bdl \\
\hline $\mathrm{CaO}$ & bdl & 1.77 & 4.80 & 6.14 & 6.54 & 2.17 & 0.77 & 6.25 & 0.59 & bdl \\
\hline $\mathrm{Al}_{2} \mathrm{O}_{3}$ & 31.86 & 26.85 & 25.75 & 26.86 & 28.00 & 26.28 & 24.44 & 27.33 & 30.21 & 32.2 \\
\hline $\mathrm{Fe}_{2} \mathrm{O}_{3}$ & bdl & 0.47 & 0.31 & 0.52 & 0.23 & 0.58 & 0.15 & 0.31 & bdl & bdl \\
\hline $\mathrm{SiO}_{2}$ & 35.20 & 36.97 & 30.83 & 33.41 & 33.80 & 33.28 & 33.52 & 33.52 & 39.83 & 42.7 \\
\hline $\mathrm{CO}_{2}$ & bdl & 0.48 & 1.35 & 0.78 & 0.24 & 1.81 & 0.82 & 0.65 & 1.66 & - \\
\hline $\mathrm{SO}_{3}$ & bdl & 9.27 & 14.97 & 10.41 & 11.56 & 11.88 & 19.01 & 13.07 & 1.42 & bdl \\
\hline $\mathbf{F}$ & bdl & 0.17 & bdl & 0.21 & 0.70 & bdl & bdl & 0.27 & 1.65 & 6.3 \\
\hline $\mathrm{Cl}$ & 7.97 & 0.37 & bdl & 0.27 & 0.45 & 0.20 & 0.56 & 0.40 & 0.62 & bdl \\
\hline$-\mathrm{O}=(\mathrm{F}, \mathrm{Cl})$ & -1.80 & -0.15 & 0 & -0.15 & -0.40 & -0.05 & -0.13 & -0.20 & -0.83 & -2.7 \\
\hline \multirow[t]{2}{*}{ Total } & 98.20 & 96.06 & 96.61 & 96.91 & 100.14 & 97.47 & $98.96^{c}$ & 100.21 & 98.19 & 100.0 \\
\hline & \multicolumn{10}{|c|}{ Formula coefficients calculated on $\mathrm{Al}+\mathrm{Si}+\mathrm{Fe}=12$ atoms per formula unit } \\
\hline $\mathrm{Na}$ & 7.98 & 5.72 & 7.05 & 6.52 & 6.61 & 7.43 & 6.66 & 6.38 & 5.86 & 6.21 \\
\hline K & 0 & 0.64 & 0 & 0.03 & 0 & 0.16 & 0.26 & 0.12 & 0.82 & 0 \\
\hline $\mathrm{Ca}$ & 0 & 0.33 & 1.00 & 1.21 & 1.26 & 0.43 & 0.16 & 1.22 & 0.10 & 0 \\
\hline $\mathrm{Al}$ & 6.20 & 5.51 & 5.93 & 5.80 & 5.91 & 5.75 & 5.54 & 5.86 & 5.66 & 5.65 \\
\hline $\mathrm{Fe}$ & 0 & 0.06 & 0.05 & 0.07 & 0.03 & 0.08 & 0.02 & 0.04 & 0 & 0 \\
\hline $\mathrm{Si}$ & 5.80 & 6.43 & 6.02 & 6.13 & 6.06 & 6.17 & 6.44 & 6.10 & 6.34 & 6.35 \\
\hline C & 0 & 0.11 & 0.36 & 0.20 & 0.06 & 0.46 & 0.22 & 0.16 & 0.36 & 0 \\
\hline$S$ & 0 & 1.21 & 2.20 & 1.43 & 1.55 & 1.66 & 2.75 & 1.78 & 0.17 & 0 \\
\hline $\mathbf{F}$ & 0 & 0.09 & 0 & 0.12 & 0.05 & 0 & 0 & 0.16 & 0.83 & 2.99 \\
\hline $\mathrm{Cl}$ & 2.22 & 0.11 & 0 & 0.08 & 0.32 & 0.06 & 0.18 & 0.12 & 0.17 & 0 \\
\hline
\end{tabular}

${ }^{a}$ Data from [17]. ${ }^{b}$ Data from [14]. ${ }^{c}$ The total includes 0.88 wt.\% of $\mathrm{H}_{2} \mathrm{O}$ which corresponds to $1.13 \mathrm{H}_{2} \mathrm{O}$ molecules. bdl: below detection limit. 
It is to be noted that the $\mathrm{CO}_{2}$ contents in Samples 2-9 correspond to the $\mathrm{CO}_{2}$ molecules in the sodalite cavities because IR spectra of these samples do not contain characteristic bands of the $\mathrm{CO}_{3}{ }^{2-}$ anion. Samples 6, 7 and 9 are characterized by abnormally high contents of carbon, sulfur and fluorine, respectively.

\subsection{Infrared Spectroscopy}

The IR spectra of the studied Samples 1-10 are given in Figures 5-8. All of them contain bands of $\mathrm{O}-\mathrm{H}$ stretching and $\mathrm{H}-\mathrm{O}-\mathrm{H}$ bending vibrations (in the ranges 3400-3700 and 1640-1660 $\mathrm{cm}^{-1}$, respectively) which are due to the presence of $\mathrm{H}_{2} \mathrm{O}$ molecules (zeolitic water). Taking into account that in the sodalite-type framework, each tetrahedral atom is coordinated by two $\mathrm{O}$ atoms, the presence of $\mathrm{OH}$ groups connected to the framework should be excluded. Additional bands in the ranges 3200-3400 and 1687-1709 $\mathrm{cm}^{-1}$ in the IR spectra of Samples $1,2,9$ and 10 may correspond to $\mathrm{H}_{3} \mathrm{O}^{+}$or $\mathrm{H}_{5} \mathrm{O}_{2}{ }^{+}$ cations [26]. This assumption is confirmed by the presence of a band in the range 1339-1358 $\mathrm{cm}^{-1}$ in the IR spectra of these four samples whereas IR spectra of other samples do not contain this band. The IR band in the range $1320-1390 \mathrm{~cm}^{-1}$ is a characteristic feature of isolated $\mathrm{H}^{+}$cation which may be formed as a result of dissociation of acid groups: $\mathrm{H}_{3} \mathrm{O}^{+} \rightarrow \mathrm{H}^{+}+\mathrm{H}_{2} \mathrm{O}_{2} \mathrm{H}_{5} \mathrm{O}_{2}{ }^{+} \rightarrow \mathrm{H}^{+}+2 \mathrm{H}_{2} \mathrm{O}$ [26].

Characteristic IR bands of S-bearing groups in the sodalite-group minerals are observed in the ranges 1124-1142 $\mathrm{cm}^{-1}$ (asymmetric stretching vibrations of the $\mathrm{SO}_{4}{ }^{2-}$ group, the $\mathrm{F}_{2}\left(v_{3}\right)$ mode), 614-637 $\mathrm{cm}^{-1}$ (bending vibrations of the $\mathrm{SO}_{4}{ }^{2-}$ group, the $\mathrm{F}_{2}\left(v_{4}\right)$ mode) and $575-585 \mathrm{~cm}^{-1}$ (antisymmetric stretching vibrations of the $\mathrm{S}_{3}{ }^{-}$radical anion, the $v_{3}$ mode-A weak band) [26-30]. Taking into account the overlapping of the bands of asymmetric stretching vibrations of the $\mathrm{SO}_{4}{ }^{2-}$ group and antisymmetric $\mathrm{T}-\mathrm{O}-\mathrm{T}$ stretching $(\mathrm{T}=\mathrm{Al}, \mathrm{Si})$ vibrations of the tetrahedral framework in the range $1020-1150 \mathrm{~cm}^{-1}$, the band in the range $614-627 \mathrm{~cm}^{-1}$ should be considered as the most reliable indication of the presence of the sulfate anion in the sodalite-group minerals. This anion was reliably detected in Samples 2-9. The characteristic band of the $\mathrm{S}_{3}{ }^{-}$radical anion is observed in the IR spectra of Samples 5 and 7. It is to be noted that the $S^{2-}$ anion does not have inner degrees of freedom and, consequently, its absorption bands could not be observed in the wavenumber range $360-3800 \mathrm{~cm}^{-1}$.

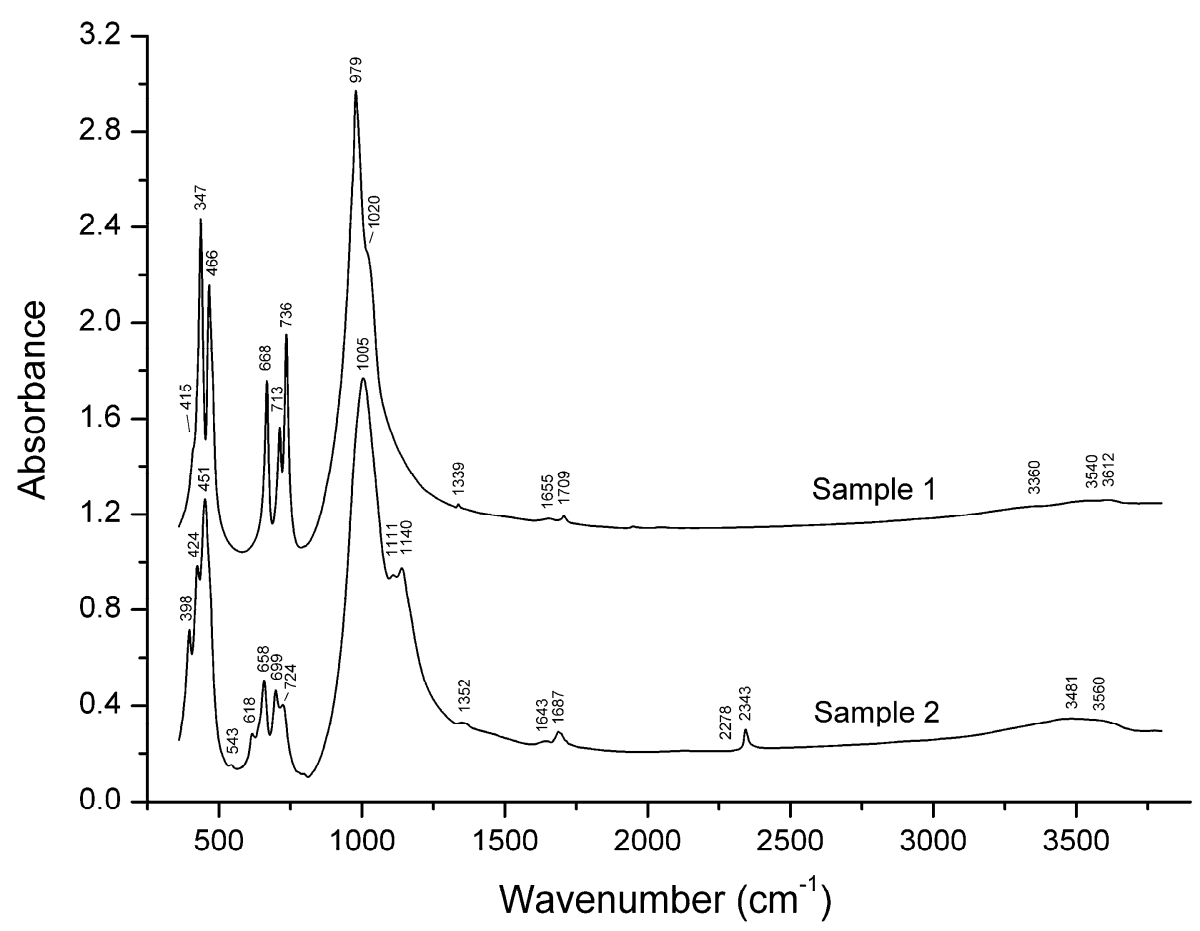

Figure 5. Infrared absorption spectra of sodalite and nosean (Samples 1 and 2). 


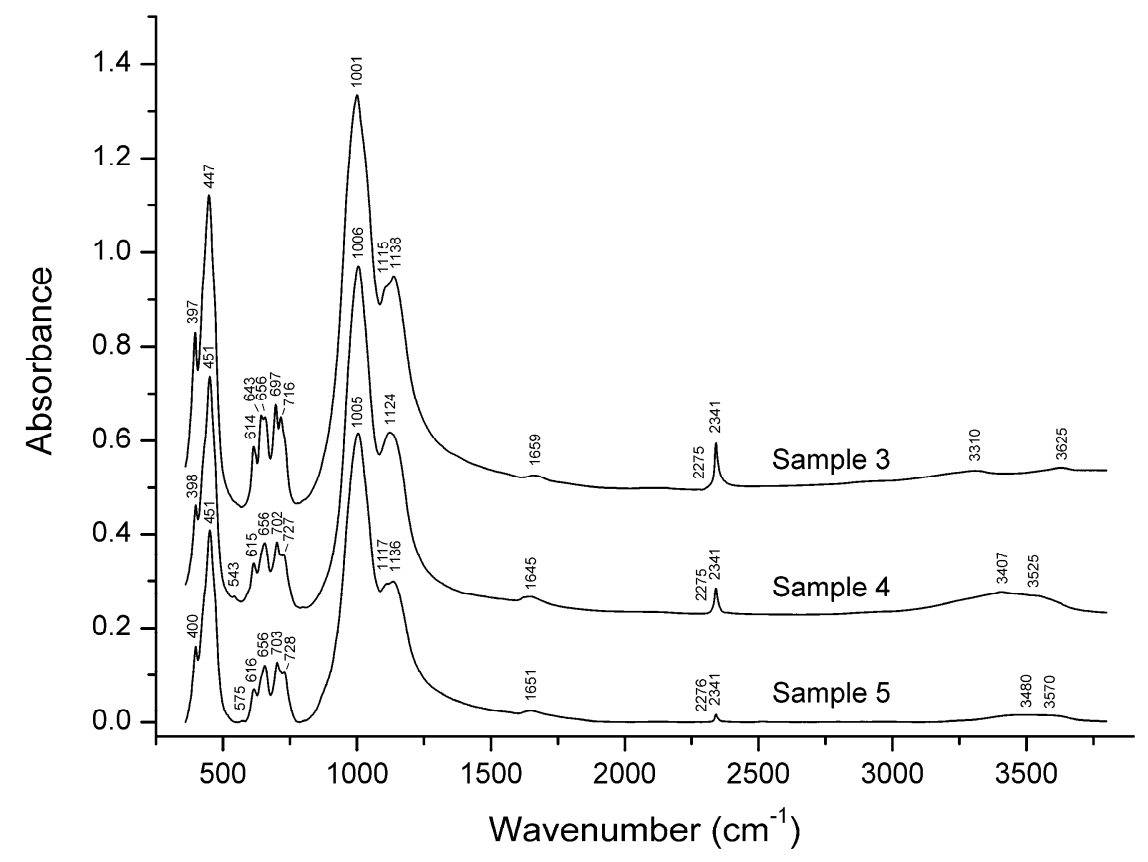

Figure 6. Infrared absorption spectra of the sulfate-rich minerals belonging to the haüyne-lazurite solid-solution series (Samples 3 to 5).

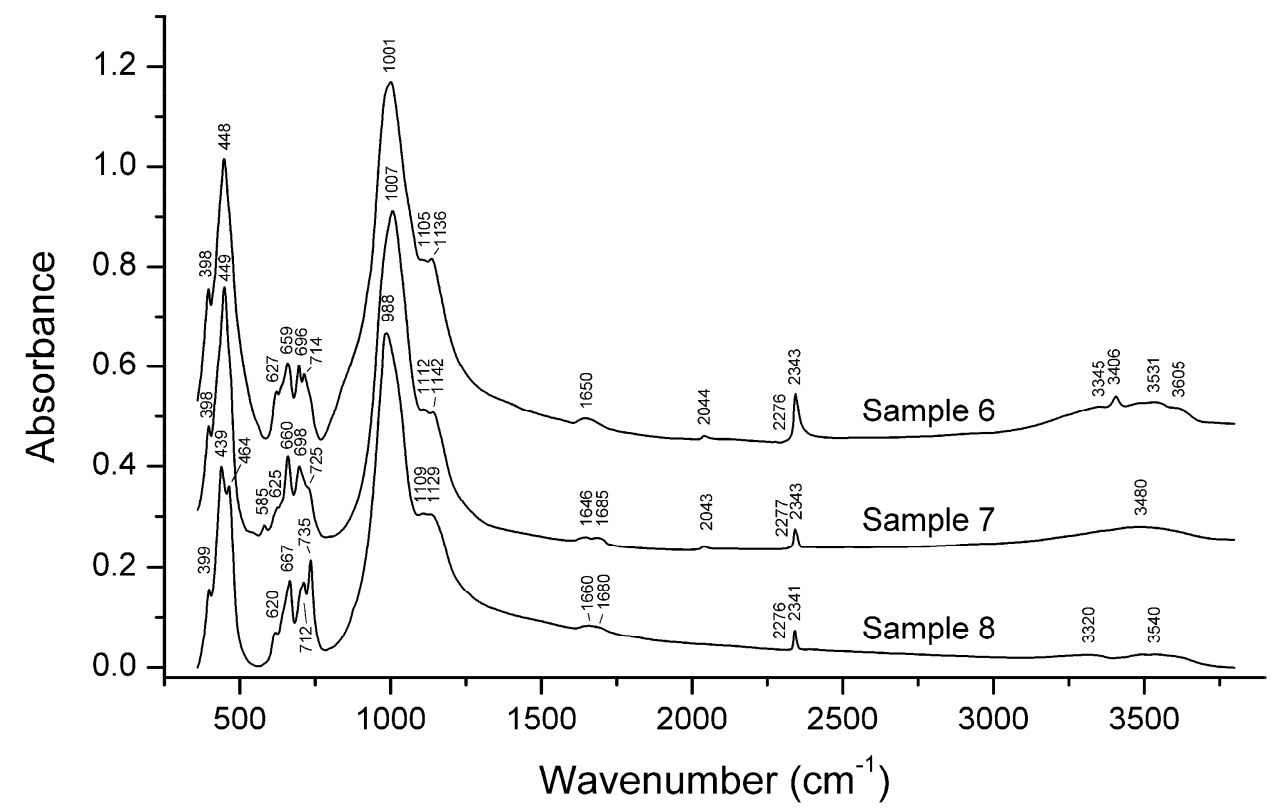

Figure 7. Infrared absorption spectra of the sulfate-poor minerals belonging to the haüyne-lazurite solid-solution series (Samples 6 to 8). 


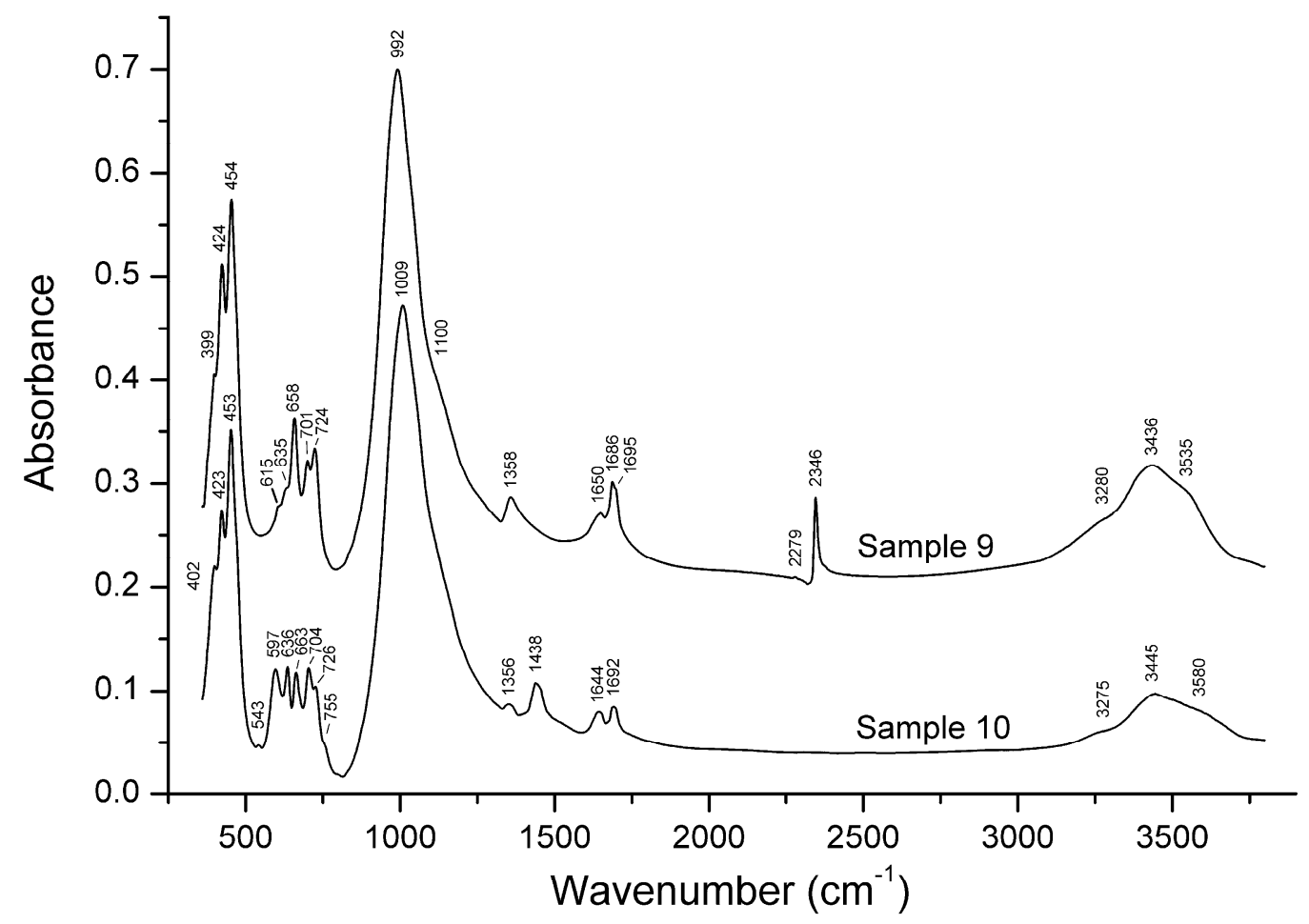

Figure 8. Infrared absorption spectra of the F-rich sodalite-group mineral (Sample 9) and synthetic fluoraluminate sodalite-type compound (Sample 10).

The three bands at about 670,710 and $740 \mathrm{~cm}^{-1}$ are proof that the sodalite-type structure exists. In some spectra, including those of Samples 3, 4 and 7, the arrangements of these three characteristic bands are disturbed. Most probably, this phenomenon is due to structure modulation, which is a characteristic feature of sodalite-type minerals from metasomatic lazurite deposits [23].

The strongest band of the $\mathrm{CO}_{3}{ }^{2-}$ group in sodalite cavities is observed in the range $1436-1450 \mathrm{~cm}^{-1}$ [30,31]. In the IR spectra of natural samples investigated in this work, this band is absent, but a band at $1438 \mathrm{~cm}^{-1}$ is observed in the IR spectrum of the synthetic sodalite-type compound, with the presumed crystal-chemical formula $\mathrm{Na}_{7.38}\left(\mathrm{Si}_{6.74} \mathrm{Al}_{5.26} \mathrm{O}_{24}\right)\left(\mathrm{AlF}_{6}\right)_{0.70} \cdot 4.88 \mathrm{H}_{2} \mathrm{O}$ (Sample 10 [14]).

The IR spectrum of Sample 10 was discussed elsewhere [15]. In accordance with structural data and by analogy with IR spectra of natural fluoraluminates [30], the band at $597 \mathrm{~cm}^{-1}$ corresponds to stretching vibrations of the $\mathrm{AlF}_{6}{ }^{3-}$ anion. This band is absent in the IR spectra of all other samples investigated in this work, including natural F-rich sodalite-type mineral (Sample 9).

A narrow band at $2341-2346 \mathrm{~cm}^{-1}$ present in the IR spectra of Samples 2-9 is due to the antisymmetric stretching vibrations of $\mathrm{CO}_{2}$ molecules [11,32]. This band is accompanied by a very weak isotope satellite at $2275-2279 \mathrm{~cm}^{-1}$ corresponding to ${ }^{13} \mathrm{C}^{16} \mathrm{O}_{2}$. Samples 3,6 and 9 are the most $\mathrm{CO}_{2}$-rich.

The optical density of the band at $2341-2346 \mathrm{~cm}^{-1}$ (D) shows positive correlation with the content of $\mathrm{CO}_{2}$ determined by selective sorption (Figure 9). Consequently, IR spectroscopy can be used for the estimation of the content of $\mathrm{CO}_{2}$ molecules in sodalite-group minerals.

We failed to assign the weak band at 2043-2044 $\mathrm{cm}^{-1}$ observed in the IR spectra of Samples 6 and 7. Hypothetically, this band may be associated with a minor admixture of an extra-framework component with the S-H covalent bond. 


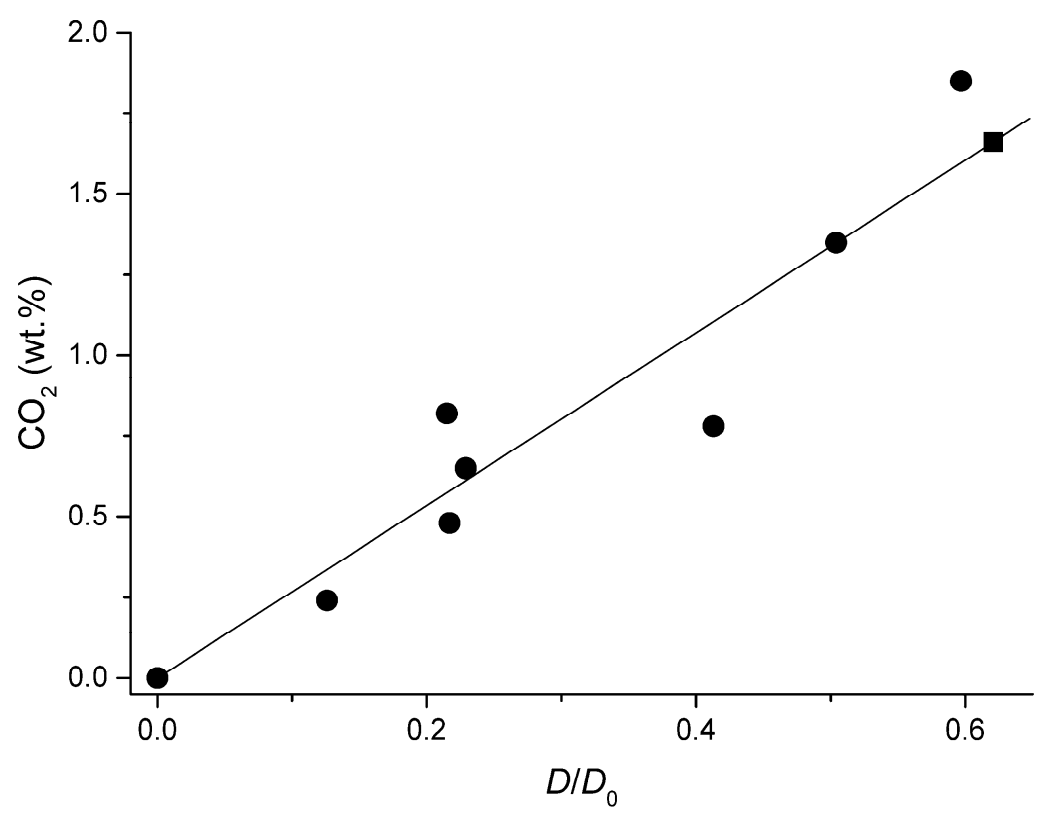

Figure 9. The correlation between the content of $\mathrm{CO}_{2}$ determined by the selective sorption and relative optical density of the band at $2341-2346 \mathrm{~cm}^{-1}\left(D_{0}\right.$ is the optical density at the maximum of the band at $656-668 \mathrm{~cm}^{-1}$ used as an internal standard). The circles correspond to Samples 1-8 and the square corresponds to Sample 9 with the $\mathrm{CO}_{2}$ content determined using this correlation.

\subsection{Raman Spectroscopy}

Among the nine minerals of the sodalite group studied in this work, there are several samples characterized by anomalous features of the chemical composition (Table 3). These are Samples 3, 6 and 9 with high contents of carbon dioxide molecules $\left(\geq 0.36 \mathrm{CO}_{2}\right.$ groups $\left.p f u\right)$, Sample 7 with a high content of sulfur (2.74 atoms $p f u$ ), and Sample 9 characterized by a very high content of fluorine (1.81 wt.\%, 0.83 atoms $p f u)$, which has never been noted in natural sodalites before. Among minerals, a higher content of $\mathrm{CO}_{2}$ molecules (2.2 wt.\%) was detected only in cordierite [33]. Figures 10 and 11 show the Raman spectra of these samples as well as the Raman spectrum of the synthetic F-rich compound with the idealized formula $\mathrm{Na}_{8}\left(\mathrm{Si}_{7} \mathrm{Al}_{5} \mathrm{O}_{24}\right)\left(\mathrm{AlF}_{6}\right) \cdot 5 \mathrm{H}_{2} \mathrm{O}$ (Sample 10).

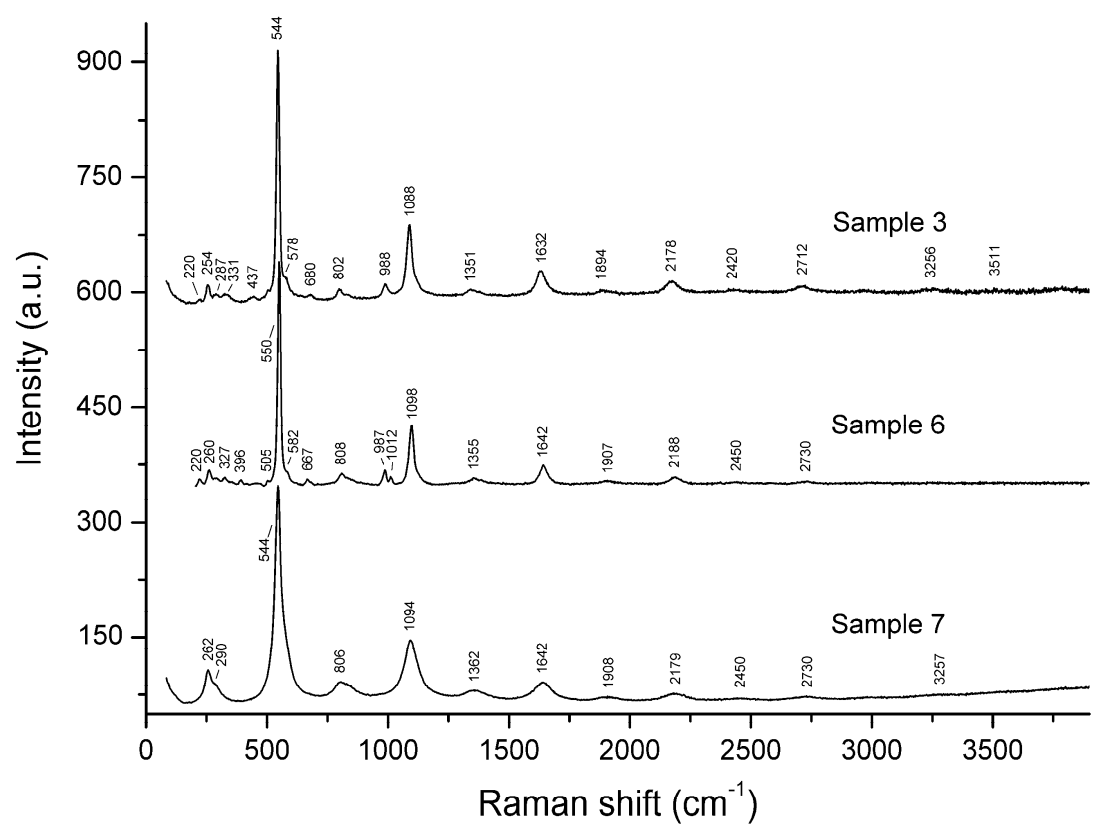

Figure 10. Raman spectra of the members of the haüyne-lazurite solid-solution series. 


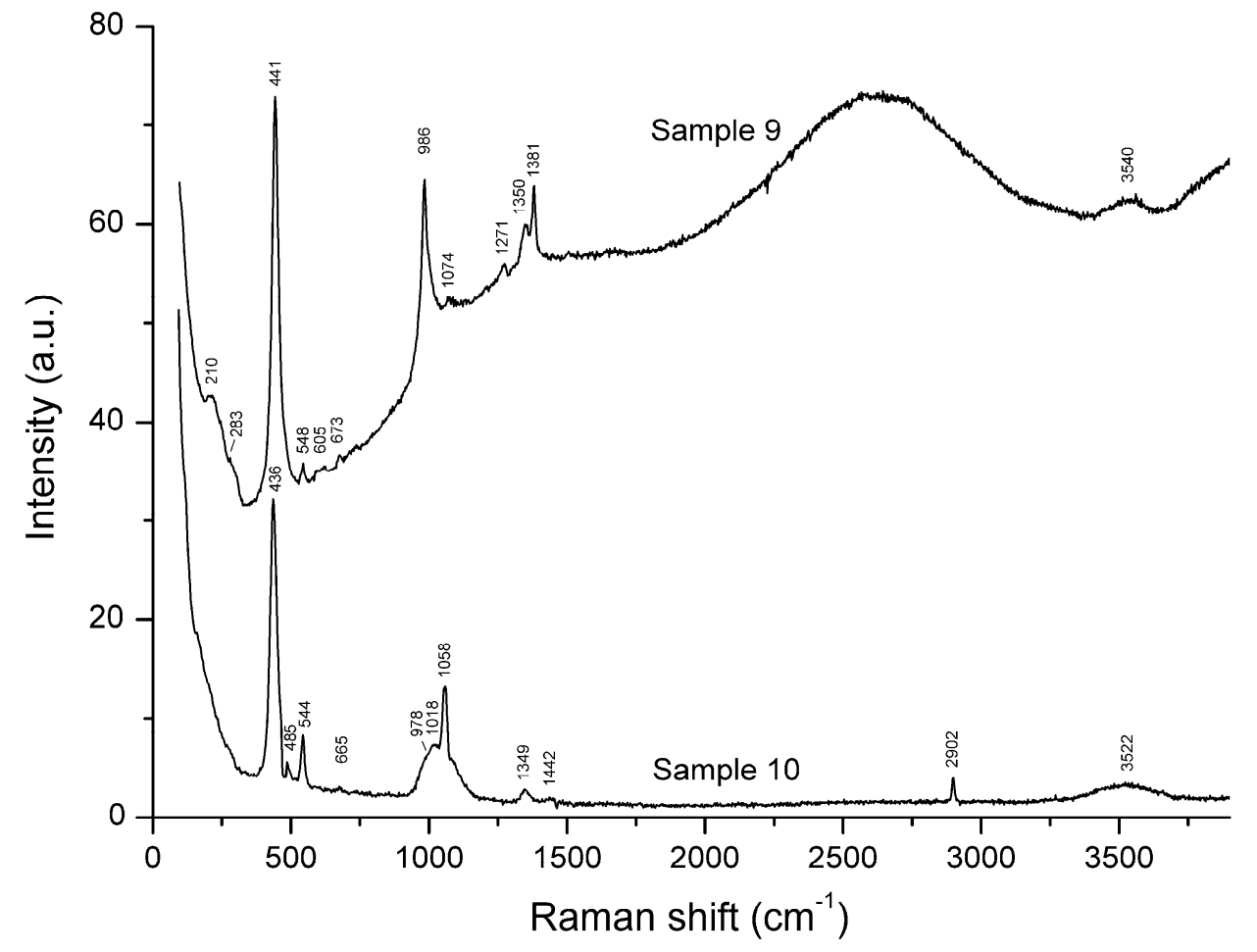

Figure 11. Raman spectra of the F-rich sodalite-group mineral (Sample 9) and the synthetic fluoraluminate sodalite-type compound (Sample 10).

The F-rich Sample 9 shows a strong luminescence under a laser beam (the broad feature in the range 1900-3200 $\mathrm{cm}^{-1}$ : Figure 11). The cause of this phenomenon is unknown. Another specific feature of the Raman spectrum of Sample 9 is the presence of the weak bands at 605 and $1074 \mathrm{~cm}^{-1}$ which are absent in the Raman spectra of other samples and may correspond to translational and librational modes of HF [34].

The assignment of Raman bands is given in Table 4. For the assignment of the bands at 327-331 and $667-680 \mathrm{~cm}^{-1}$ to the vibrations of the $\mathrm{S}_{4}^{-}$radical anion, see the Discussion section.

Table 4. Raman bands of sodalite-group minerals and Sample 10, and their assignment.

\begin{tabular}{|c|c|c|c|c|c|}
\hline Sample 3 & Sample 6 & Sample 7 & Sample 9 & Sample 10 & Assignment \\
\hline \multicolumn{6}{|c|}{ Raman Shift $\left(\mathrm{cm}^{-1}\right)$} \\
\hline $220 w$ & $220 w$ & & 210 & & $\begin{array}{l}\text { Combination of low-frequency lattice } \\
\text { modes }\end{array}$ \\
\hline 254 & 265 & 262 & & & $\mathrm{~S}_{3}-$ bending $\left(v_{2}\right)$ \\
\hline $287 w$ & & $290 \mathrm{sh}$ & $283 \mathrm{sh}$ & & $\begin{array}{l}\text { Combination of low-frequency lattice } \\
\text { modes }\end{array}$ \\
\hline \multirow[t]{2}{*}{$331 w$} & $327 w$ & & & & $\mathrm{~S}_{4}{ }^{-}$symmetric stretching $\left(v_{1}-\mathrm{A}_{1}\right)$ \\
\hline & 396 & & & & Anhydrite admixture \\
\hline \multirow[t]{3}{*}{$437 w$} & & & $441 \mathrm{~s}$ & $436 \mathrm{~s}$ & $\begin{array}{l}\mathrm{SO}_{4} \text { bending and/or } \\
\delta[\mathrm{O}-\mathrm{Si}(\mathrm{Al})-\mathrm{O}]\end{array}$ \\
\hline & & & & 485 & $\mathrm{AlF}_{6}$ stretching. \\
\hline & $505 w$ & & & & Anhydrite admixture \\
\hline $544 \mathrm{~s}$ & $550 \mathrm{~s}$ & $544 \mathrm{~s}$ & $548 w$ & 544 & $\begin{array}{c}\mathrm{S}_{3}{ }^{-} \text {symmetric stretching }\left(v_{1}\right) \text { and/or } \\
\mathrm{AlF}_{6} \text { stretching }\end{array}$ \\
\hline
\end{tabular}


Table 4. Cont.

\begin{tabular}{|c|c|c|c|c|c|}
\hline Sample 3 & Sample 6 & Sample 7 & Sample 9 & Sample 10 & Assignment \\
\hline \multicolumn{6}{|c|}{ Raman Shift $\left(\mathrm{cm}^{-1}\right)$} \\
\hline \multirow[t]{3}{*}{$578 \mathrm{sh}$} & $582 \mathrm{sh}$ & & & & $\mathrm{S}_{3}{ }^{-}$antisymmetric stretching $\left(v_{3}\right)$ \\
\hline & & & $605 w$ & & HF translational mode \\
\hline & & & $673 w$ & $665 w$ & HF translational mode? \\
\hline $680 w$ & $667 w$ & & & & $\mathrm{~S}_{4}{ }^{-}$stretching $\left(v_{3}-\mathrm{E}\right)$ \\
\hline 802 & 808 & 806 & & & $\mathrm{~S}_{3}{ }^{-}$combination mode $\left(v_{1}+v_{2}\right)$ \\
\hline \multirow[t]{5}{*}{988} & 987 & & $986 \mathrm{~s}$ & 978 sh & $\begin{array}{l}\mathrm{SO}_{4} \text { symmetric stretching and/or } \\
\text { stretching vibrations of the framework }\end{array}$ \\
\hline & $1012 w$ & & & & Anhydrite admixture \\
\hline & & & & 1018 br & Admixture of aluminosilicate glass \\
\hline & & & & $1058 \mathrm{~s}$ & $\mathrm{CO}_{3}$ symmetric stretching \\
\hline & & & $1074 w$ & & HF librational mode \\
\hline \multirow[t]{3}{*}{$1088 \mathrm{~s}$} & $1098 \mathrm{~s}$ & $1094 \mathrm{~s}$ & & & $\mathrm{~S}_{3}{ }^{-}$overtone $\left(2 \times v_{1}\right)$ \\
\hline & & & $1271 \mathrm{w}$ & & $\mathrm{CO}_{2}$ Fermi resonance \\
\hline & & & 1350 & 1349 & $\mathrm{H}^{+}$ \\
\hline \multirow[t]{3}{*}{1351} & 1355 & 1362 & & & $\mathrm{~S}_{3}{ }^{-}$combination mode $\left(2 v_{1}+v_{2}\right)$ \\
\hline & & & 1381 & & $\mathrm{CO}_{2}$ Fermi resonance \\
\hline & & & & $1442 w$ & $\mathrm{CO}_{3}$ asymmetric stretching \\
\hline 1632 & 1642 & 1642 & & & $\mathrm{~S}_{3}{ }^{-}$overtone $\left(3 \times v_{1}\right)$ \\
\hline 1894 & $1907 w$ & $1908 w$ & & & $\mathrm{~S}_{3}{ }^{-}$combination mode $\left(3 \times v_{2}+v_{1}\right)$ \\
\hline 2178 & 2188 & 2179 & & & $\mathrm{~S}_{3}{ }^{-}$overtone $\left(4 \times v_{1}\right)$ \\
\hline $2420 w$ & $2450 w$ & $2450 w$ & & & $\mathrm{~S}_{3}{ }^{-}$combination mode $\left(4 \times v_{2}+v_{1}\right)$ \\
\hline \multirow[t]{2}{*}{2712} & $2730 w$ & $2730 w$ & & & $\mathrm{~S}_{3}{ }^{-}$overtone $\left(5 \times v_{1}\right)$ \\
\hline & & & & 2902 & $\mathrm{CH}_{4}$ \\
\hline 3256 & & $3257 w$ & & & $\mathrm{~S}_{3}{ }^{-}$overtone $\left(6 \times v_{1}\right)$ \\
\hline $3511 w$ & & & 3540 & 3522 & $\mathrm{H}_{2} \mathrm{O}$ stretching vibrations \\
\hline
\end{tabular}

Note: w-weak band, s—strong band, sh—shoulder, br-broad band.

\subsection{X-ray Diffraction Data and Crystal Structure}

The studied sample of the F-rich sodalite-group mineral (Sample 9) retains the sodalite-type framework built by corner-linked $\mathrm{TO}_{4}$ tetrahedra $(T=\mathrm{Si}, \mathrm{Al})$. Extra-framework cations $\left(\mathrm{Na}^{+}\right.$and subordinate $\mathrm{K}^{+}$and $\mathrm{Ca}^{2+}$ statistically replacing each other), anions $\left(\mathrm{F}^{-}, \mathrm{Cl}^{-}, \mathrm{SO}_{4}{ }^{2-}\right)$ and neutral molecules $\left(\mathrm{H}_{2} \mathrm{O}, \mathrm{CO}_{2}\right)$ occur in $\beta$-cages. The refined $\mathrm{F}$ content of 1.54 apfu is significantly higher than the value of $0.83 \mathrm{~F}$ apfu in the empirical formula. On the other hand, no separate sites were found for $\mathrm{H}_{2} \mathrm{O}$ and $\mathrm{CO}_{2}$ molecules. For this reason, we assume that these components may replace $\mathrm{F}$ anions. Additional water molecules may occur with a very low occupancy around $\mathrm{O}$ atoms of $\mathrm{SO}_{4}$ tetrahedron (OS). The Na site is split onto three subsites with partial occupancies. The site occupancy factors for all Na subsites were refined using Na scattering curve and $U_{\text {anis }}$ restrained to be equal; then, $\mathrm{K}(\mathrm{K}=\mathrm{K}+\mathrm{Ca})$ admixture was added according to chemical data and the refined number of electrons.

Atom coordinates and displacement parameters for Sample 9 are given in Table 5 and interatomic distances in Table 6. The crystal structure of Sample 9 is shown in Figure 12. 
Table 5. Atom coordinates, equivalent displacement parameters (in $\AA^{2}$ ), site occupancy factors (s.o.f.) and site multiplicities $(Q)$ for the Sample 9.

\begin{tabular}{ccccccc}
\hline Site & $\boldsymbol{x}$ & $\boldsymbol{y}$ & $\boldsymbol{z}$ & $\boldsymbol{U}_{\text {eq }}$ & s.o.f $^{*}$ & $Q$ \\
\hline$T$ & 0.25 & 0.5 & 0.0 & $0.0102(5)$ & $\mathrm{Si}_{0.528} \mathrm{Al}_{0.472}$ & 12 \\
$\mathrm{O}$ & $0.1480(4)$ & $0.1480(4)$ & $0.4605(5)$ & $0.0275(12)$ & $\mathrm{O}_{1.00}$ & 24 \\
$\mathrm{Na} 1$ & $0.297(4)$ & $0.297(4)$ & $0.297(4)$ & $0.060(8)$ & $\mathrm{Na}_{0.159 \mathrm{~K}_{0.024}}$ & 8 \\
$\mathrm{Na} 2$ & $0.164(3)$ & $0.164(3)$ & $0.164(3)$ & $0.060(8)$ & $\mathrm{Na}_{0.288} \mathrm{~K}_{0.045}$ & 8 \\
$\mathrm{Na} 3$ & $0.198(3)$ & $0.198(3)$ & $0.198(3)$ & $0.060(8)$ & $\mathrm{Na}_{0.288} \mathrm{~K}_{0.045}$ & 8 \\
$\mathrm{Cl}, \mathrm{S}$ & 0.0 & 0.0 & 0.0 & $0.024(4)$ & $\mathrm{Cl}_{0.096} \mathrm{~S}_{0.078}$ & 2 \\
$\mathrm{OS}$ & $0.4074(16)$ & $0.4074(16)$ & $0.4074(16)$ & $0.024(4)$ & $\mathrm{O}_{0.078}$ & 8 \\
$\mathrm{~F}$ & 0.0 & 0.0 & $0.191(4)$ & $0.034(10)$ & $\mathrm{F}_{0.128}$ & 12 \\
\hline
\end{tabular}

* Fixed on the last stages of the refinement, taking into account both structural and chemical data, except $\mathrm{F}$ site which showed the s.o.f. significantly higher and is assumed to be partially replaced by $\mathrm{H}_{2} \mathrm{O}$ and/or $\mathrm{CO}_{2}$.

Table 6. Selected interatomic distances (Å) in the structure of Sample 9.

$\begin{array}{llll}\mathrm{Na} 1-\mathrm{O} & 2.415(19) \times 3 & \mathrm{Na} 3-\mathrm{O} & 2.462(16) \times 3 \\ -\mathrm{F} & 2.61(5) \times 3 & -\mathrm{F} & 2.54(3) \times 3 \\ -\mathrm{O} & 3.13(2) \times 3 & -\mathrm{O} & 2.919(7) \times 3 \\ -\mathrm{Cl} & 3.19(6) & -\mathrm{OS} & 2.96(4) \times 3 \\ & & -\mathrm{Cl} & 3.11(4) \\ \mathrm{Na} 2 *-\mathrm{OS} & 2.50(4) \times 3 & \mathrm{~T}-\mathrm{O} & 1.6671(14) \times 4 \\ -\mathrm{O} & 2.70(2) \times 3 & \mathrm{~S}-\mathrm{OS} & 1.45(2) \times 4 \\ -\mathrm{O} & 3.035(13) \times 3 & & \end{array}$

* The Na2 subsite is connected with $\mathrm{F}$ and $\mathrm{Cl}$ atoms with short distances of $2.11 \AA$ (Na2-F) and $2.57 \AA(\mathrm{Na} 2-\mathrm{Cl})$; for this reason, these bonds were excluded from the coordination sphere of $\mathrm{Na} 2$.

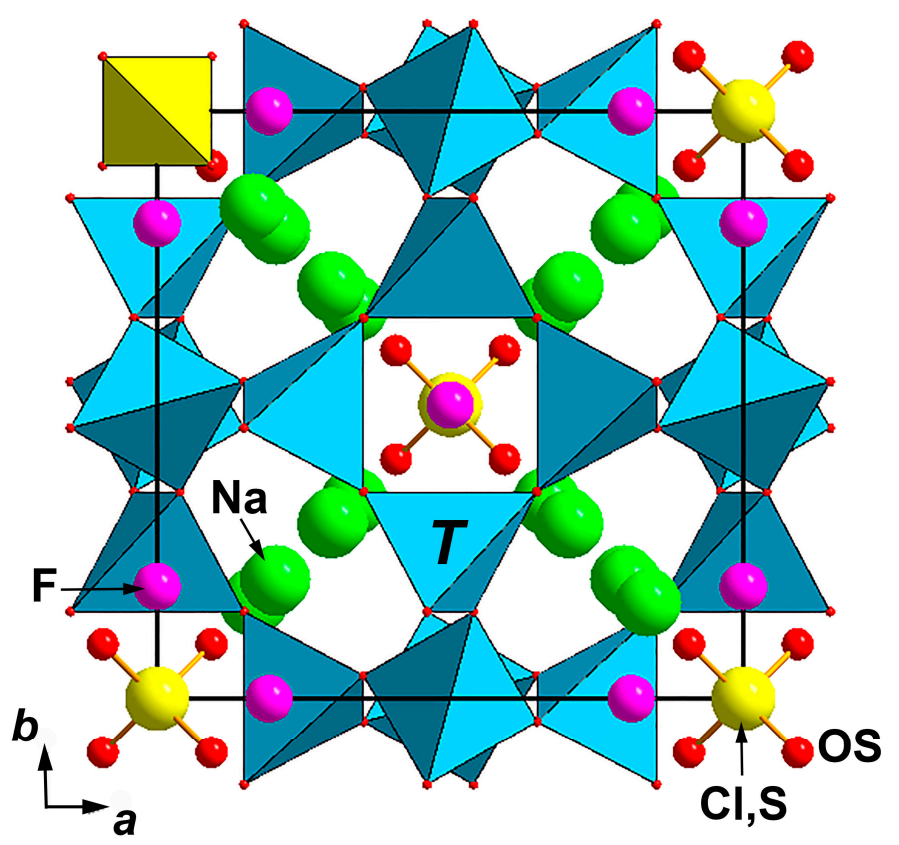

Figure 12. The crystal structure of the F-rich sodalite-group mineral (Sample 9).

\section{Discussion}

The empirical formulae of the studied sodalite-group minerals were calculated based on chemical data (Table 3) and taking into account the above data on the infrared and Raman spectra. According to the spectroscopic data, the anomalously high-sulfur Sample 7 from Sar-e Sang (the type locality of lazurite) has a high content of the radical anions $\mathrm{S}_{3}{ }^{-}$and a low content of the $\mathrm{SO}_{4}{ }^{2-}$ groups; other polysulfide anions are absent, and the presence of the 
monosulfide anion $\mathrm{S}^{2-}$ cannot be excluded. Consequently, the charge-balanced formula of Sample 7 is $\left(\mathrm{Na}_{6.66} \mathrm{~K}_{0.26} \mathrm{Ca}_{0.16}\right)\left(\mathrm{Si}_{6.44} \mathrm{Al}_{5.54} \mathrm{Fe}^{3+}{ }_{0.02} \mathrm{O}_{24}\right)\left(\mathrm{S}_{3}{ }^{-}\right)_{0.80}\left(\mathrm{~S}^{2-}, \mathrm{SO}_{4}{ }^{2-}\right)_{0.35} \mathrm{Cl}_{0.18}\left(\mathrm{CO}_{2}\right)_{0.22} \cdot 1.13 \mathrm{H}_{2} \mathrm{O}$. The idealized formula of this sample is $\mathrm{Na}_{7}\left(\mathrm{Si}_{6} \mathrm{Al}_{6} \mathrm{O}_{24}\right)\left(\mathrm{S}_{3}{ }^{-}\right) \cdot \mathrm{H}_{2} \mathrm{O}$. This formula differs significantly from the idealized formula $\mathrm{Na}_{3} \mathrm{Ca}\left(\mathrm{Si}_{3} \mathrm{Al}_{3}\right) \mathrm{O}_{12} \mathrm{~S}$ (another spelling being $\mathrm{Na}_{6} \mathrm{Ca}_{2}\left(\mathrm{Si}_{6} \mathrm{Al}_{6} \mathrm{O}_{24}\right) \mathrm{S}^{2-}{ }_{2}$ ) of lazurite given in the current IMA list of mineral species [35] together with the reference [9]. Moreover, the latter formula contradicts the results of X-ray structural analysis of "lazurite" from [9], which correspond to a $\mathrm{SO}_{4}$-dominant mineral.

The charge-balanced empirical formula of another sample from Sar-e Sang (Sample 8) is $\left(\mathrm{Na}_{6.38} \mathrm{Ca}_{1.22} \mathrm{~K}_{0.12}\right)\left(\mathrm{Si}_{6.10} \mathrm{Al}_{5.86} \mathrm{Fe}^{3+}{ }_{0.04} \mathrm{O}_{24}\right)\left(\mathrm{S}^{2-}, \mathrm{SO}_{4}{ }^{2-}\right)_{1.30}\left(\mathrm{~S}_{3}{ }^{-}\right)_{0.16}\left(\mathrm{CO}_{2}\right)_{0.16} \cdot n \mathrm{H}_{2} \mathrm{O}_{\text {, }}$ which is close to the lazurite formula from the IMA list of mineral species. The charge-balanced formula of one more $S^{2-}$-dominant lazurite sample (Sample 3) is $\left(\mathrm{Na}_{7.05} \mathrm{Ca}_{1.00}\right)\left(\mathrm{Si}_{6.02} \mathrm{Al}_{5.93} \mathrm{Fe}^{3+}{ }_{0.05} \mathrm{O}_{24}\right)\left(\mathrm{S}^{2-}, \mathrm{SO}_{4}{ }^{2-}\right)_{1.40}\left(\mathrm{~S}_{3}{ }^{-}\right)_{0.27}\left(\mathrm{CO}_{2}\right)_{0.36} \cdot n \mathrm{H}_{2} \mathrm{O}$. These examples show that several different sulfide members of the sodalite group (with different contents of $\mathrm{Ca}, \mathrm{H}_{2} \mathrm{O}$ and $\mathrm{CO}_{2}$ and with different dominant sulfide groups) may exist, and the status of lazurite as a mineral species needs to be specified.

The charge-balanced empirical formula of the most $\mathrm{CO}_{2}$-rich lazurite (Sample 6) is $\left(\mathrm{Na}_{7.43} \mathrm{~K}_{0.16} \mathrm{Ca}_{0.43}\right)\left(\mathrm{Si}_{6.17} \mathrm{Al}_{5.75} \mathrm{Fe}^{3+}{ }_{0.08} \mathrm{O}_{24}\right)\left(\mathrm{S}^{2-}, \mathrm{SO}_{4}{ }^{2-}\right)_{1.21}\left(\mathrm{~S}_{3}{ }^{-}\right)_{0.15} \mathrm{Cl}_{0.06}\left(\mathrm{CO}_{2}\right)_{0.46} \cdot n \mathrm{H}_{2} \mathrm{O}$ (here, we neglected trace amounts of the $\mathrm{S}_{4}^{-}$anions showing a weak Raman band at $327 \mathrm{~cm}^{-1}$ ). Taking into account the low intensities of the bands of sulfate groups in the IR spectrum of Sample 6, one can conclude that in this sample, sulfate anion plays a subordinate role. Consequently, the idealized formula of Sample 6 is $\mathrm{Na}_{8}\left(\mathrm{Si}_{6} \mathrm{Al}_{6} \mathrm{O}_{24}\right) \mathrm{S}^{2-} \cdot n \mathrm{H}_{2} \mathrm{O}$, which also differs significantly from the formula $\mathrm{Na}_{6} \mathrm{Ca}_{2}\left(\mathrm{Si}_{6} \mathrm{Al}_{6} \mathrm{O}_{24}\right) \mathrm{S}^{2-}{ }_{2}$ accepted currently for lazurite. Moreover, one cannot exclude the existence of a sulfide sodalite-group mineral with species-defining $\mathrm{CO}_{2}$ molecules. A higher $\mathrm{CO}_{2}$ content (2.70 wt.\%) was detected in nosean from Bassano Romano, Viterbo, Lazio, Italy [11], but this sample is characterized by a relatively low intensity of the stretching band of carbon dioxide and, therefore, most of the carbon in it belongs to carbonate anions.

Structural carbon dioxide is a typical admixed component of different silicate minerals with microporous and channel structures. The well-known examples are different members of the cancrinite group [36-40], cordierite [41-44], beryl [45,46], pollucite [47], melanophlogite [48] etc. Sodalite-group minerals are not an exclusion from this trend.

The radical ion $\left(\mathrm{S}_{3}\right)^{-}$is considered by most researchers as the main cause of blue color of lazurite [49-56]. Our data confirm this conclusion.

In the review [57], it is stated that "The radical anion [S-S-S-S]"- has not yet been observed convincingly by Raman spectroscopy". However, it is to be noted that the structure and Raman spectrum of the tetrasulfide radical anion is discussed in detail in [54]. The authors of this paper concluded that $\left(\mathrm{S}_{4}\right)^{-}$has the flat star shape, $D 3 h$. The calculated wavenumbers of Raman active bands $v_{1}(\mathrm{~A} 1)=329, v_{3}(E)=680$, and $v_{4}(E)=345 \mathrm{~cm}^{-1}$ are in excellent agreement with experimental data. The intensities of the bands $v_{1}$ and $v_{3}$ are nearly equal, whereas $v_{4}$ is observed as a weak shoulder. In our Raman spectra of Samples 3 and 6 , the weak bands $v_{1}$ and $v_{3}$ also have nearly equal intensities, and the band $v_{4}$ is not observed. In the Raman spectra of F-rich and S-depleted Samples 9 and 10, the bands at 673 and 665, which are not accompanied by the bands in the range $320-340 \mathrm{~cm}^{-1}$, are tentatively assigned to the vibrations of the HF molecule as a whole, in accordance with [34].

The IR and Raman spectra indicate that F-rich Sample 9 contains sulfate groups, $\mathrm{H}_{2} \mathrm{O}$ and $\mathrm{CO}_{2}$ molecules. As noted above, the band at $1350-1358 \mathrm{~cm}^{-1}$ observed in both IR and Raman spectra may correspond to vibrations of the $\mathrm{H}^{+}$cation in the $\beta$-cage. Unlike the synthetic F-rich sodalite-type compound (Sample 10), Sample 9 does not show IR and Raman bands of the $\mathrm{AlF}_{6}{ }^{3-}$ anion. Consequently, the empirical formula of the latter sample is $\mathrm{H}^{+}{ }_{0.12}\left(\mathrm{Na}_{5.86} \mathrm{~K}_{0.82} \mathrm{Ca}_{0.10}\right)\left(\mathrm{Si}_{6.34} \mathrm{Al}_{5.66} \mathrm{O}_{24}\right) \mathrm{F}_{0.83} \mathrm{Cl}_{0.17}\left(\mathrm{SO}_{4}\right)_{0.17}\left(\mathrm{CO}_{2}\right)_{0.36} \cdot n \mathrm{H}_{2} \mathrm{O}$. The addition of $\mathrm{H}^{+}$in the empirical formula is formally required for the charge balance, and is in agreement with the above assumption that Sample 10 contains additional $\mathrm{H}^{+}$cation. The most interesting feature of 
Sample 9 is a significant predominance of $\mathrm{F}^{-}$over all other extra-framework anions, which makes it possible to consider this mineral as a potentially new mineral species with the idealized formula $\mathrm{Na}_{7}\left(\mathrm{Si}_{6} \mathrm{Al}_{6} \mathrm{O}_{24}\right) \mathrm{F}^{-} \cdot n \mathrm{H}_{2} \mathrm{O}$. Most probably, this mineral crystallized at high fugacities of $\mathrm{HF}$ and $\mathrm{CO}_{2}$.

Hypothetically, anionic and neutral extra-framework components $\left(\mathrm{Cl}^{-}, \mathrm{OH}^{-}, \mathrm{F}^{-}, \mathrm{AlF}_{6}{ }^{3-}, \mathrm{SO}_{4}{ }^{2-}\right.$, $\mathrm{S}^{2-}, \mathrm{S}_{3}{ }^{-}, \mathrm{CO}_{3}{ }^{2-}, \mathrm{C}_{2} \mathrm{O}_{4}{ }^{2-}, \mathrm{CO}_{2}, \mathrm{H}_{2} \mathrm{O}, \mathrm{CH}_{4}$ etc.) occurring in $\beta$-cages of minerals belonging to the sodalite and cancrinite groups could be used as important geochemical markers, provided that the relationships between their contents and conditions of mineral formation will be investigated in detail experimentally. In particular, one can suppose that the ratios $\mathrm{SO}_{4}{ }^{2-}:\left(\mathrm{S}^{2-}+\mathrm{S}_{3}{ }^{-}\right)$and $\left(\mathrm{CO}_{3}{ }^{2-}+\mathrm{CO}_{2}\right)$ : $\mathrm{C}_{2} \mathrm{O}_{4}{ }^{2-}: \mathrm{CH}_{4}$ may reflect oxygen fugacity in the mineral-forming medium. The geochemical role of different S-bearing species, including the trisulfur radical anion, is discussed in $[29,58]$.

Author Contributions: N.V.C. and I.V.P. wrote the paper. N.V.C. obtained and interpreted the IR spectra. M.F.V. obtained and interpreted the Raman spectra. N.V.Z. solved the crystal structure. D.Y.P. carried out the crystal-chemical analysis. I.V.P. obtained the crystal data. C.S. and A.V.K. collected the samples 6 and 9, respectively. V.O.Y. obtained electron-microprobe data. All authors have read and agreed to the published version of the manuscript.

Funding: This work was supported by the Russian Foundation for Basic Research, grants nos. 18-29-12007-mk (Raman spectroscopy) and by the Russian Science Foundation, grant no. 19-17-00050 (crystal structure analysis). A part of this work (IR spectroscopy and a part of chemical analyses) has been carried out in accordance with the state task, state registration number AAAA-A19-119092390076-7. The authors are grateful to A.N. Saposhnikov and A.R. Kotelnikov for samples provided for the investigations.

Conflicts of Interest: The authors declare no conflict of interest.

\section{References}

1. Taylor, D. The sodalite group of minerals. Contrib. Mineral. Petrol. 1967, 16, 172-188. [CrossRef]

2. Sahl, K.; Chatterjee, N.D. The crystal structure of bicchulite, $\mathrm{Ca}_{2}\left[\mathrm{Al}_{2} \mathrm{SiO}_{6}\right](\mathrm{OH})_{2}$. Zeits. Krist. 1977, 146, 35-41. [CrossRef]

3. Sahl, K. Refinement of the crystal structure of bicchulite, $\mathrm{Ca}_{2}\left[\mathrm{Al}_{2} \mathrm{SiO}_{6}\right](\mathrm{OH})_{2}$. Zeits. Krist. 1980, $152,13-21$. [CrossRef]

4. Uchida, E.; Iiyama, J.T. On kamaishilite, $\mathrm{Ca}_{2} \mathrm{Al}_{2} \mathrm{SiO}_{6}(\mathrm{OH})_{2}$; a new mineral (tetragonal), dimorphous with bicchulite, from the Kamaishi mine, Japan. Proc. Jpn. Acad. 1981, 57B, 239-243. (In English) [CrossRef]

5. Peterson, R.C. The structure of hackmanite, a variety of sodalite, from Mont St-Hilaire, Quebec. Can. Mineral. 1983, 21, 549-552.

6. Hassan, I.; Grundy, H.D. The crystal structures of sodalite-group minerals. Acta Cryst. 1984, B40, 6-13. [CrossRef]

7. Hassan, I.; Buseck, P. Cluster ordering and antiphase domain boundaries in hauyne. Can. Mineral. 1989, 27, 173-180.

8. Hassan, I.; Grundy, H.D. The structure of nosean, ideally $\mathrm{Na}_{8}\left[\mathrm{Al}_{6} \mathrm{Si}_{6} \mathrm{O}_{24}\right] \mathrm{SO}_{4} \cdot \mathrm{H}_{2}$ O. Can. Mineral. 1989, 27, 165-172.

9. Hassan, I.; Peterson, R.C.; Grundy, H.D. The structure of lazurite, ideally $\mathrm{Na}_{6} \mathrm{Ca}_{2}\left(\mathrm{Al}_{6} \mathrm{Si}_{6} \mathrm{O}_{24}\right) \mathrm{S}_{2}$, a member of the sodalite group. Acta Cryst. C 1985, 41, 827-832. [CrossRef]

10. Gobeltz-Hautecoeur, N.; Demortier, A.; Lede, B.; Lelieur, J.P.; Duhayon, C. Occupancy of the sodalite cages in the blue ultramarine pigments. Inorg. Chem. 2002, 41, 2848-2854. [CrossRef]

11. Bellatreccia, F.; Della Ventura, G.; Piccinini, M.; Cavallo, A.; Brilli, $\mathrm{M}$. $\mathrm{H}_{2} \mathrm{O}$ and $\mathrm{CO}_{2}$ in minerals of the hauyne-sodalite group: A FTIR spectroscopy study. Mineral. Mag. 2009, 73, 399-413. [CrossRef]

12. Fechtelkord, $\mathrm{M}$. Structural study of $\mathrm{Na}_{8}\left[\mathrm{AlSiO}_{4}\right]_{6}\left(\mathrm{CO}_{3}\right)_{\mathrm{x}}(\mathrm{HCOO})_{2-2 \mathrm{x}}\left(\mathrm{H}_{2} \mathrm{O}\right)_{4 \mathrm{x}}, 0.2 \leq \mathrm{x} \leq 1$, synthesized in organic solvents: Order and disorder of carbonate and formate anions in sodalite. Micropor. Mesopor. Mater. 1999, 28, 335-351. [CrossRef]

13. Gesing, T.M.; Buhl, J.C. Crystal structure of a carbonate-nosean $\mathrm{Na}_{8}\left[\mathrm{AlSiO}_{4}\right]_{6} \mathrm{CO}_{3}$. Eur. J. Miner. 1998, 10, 71-77. [CrossRef]

14. Yakubovich, O.V.; Kotel'nikov, A.R.; Shchekina, T.I.; Gramenitskiy, E.N.; Zubkov, E.S. New representative in the sodalite structure type with extraframework anions $\left[\mathrm{AlF}_{6}\right]^{3-}$. Crystallogr. Rep. 2011, 56, 190-197. [CrossRef] 
15. Gramenitskii, E.N.; Kotel'nikov, A.R.; Shchekina, T.I.; Yakubovich, O.V.; Devyatova, V.N.; Zubkov, E.S.; Suk, N.I.; Vigasina, M.F.; Kotel'nikova, Z.A. Composition, structure and conditions of formation of fluorine-containing sodalite (experimental data). Geochem. Int. 2018, 56, 521-534. [CrossRef]

16. Hassan, I.; Grundy, H.D. The crystal structure of basic cancrinite, ideally $\mathrm{Na}_{8}\left[\mathrm{Al}_{6} \mathrm{Si}_{6} \mathrm{O}_{24}\right](\mathrm{OH})_{2} \cdot 3 \mathrm{H}_{2} \mathrm{O}$. Can. Mineral. 1991, 29, 123-130.

17. Nishanbaev, T.P.; Rassomahin, M.A.; Blinov, I.A.; Popova, V.I. Minerals of sodalite-cancrinite pegmatites from the Vishnevogorsk miaskite massif, South Urals. Mineralogy 2016, 3, 40-52. (In Russian)

18. Schmitt, A.K.; Wetzel, F.; Cooper, K.M.; Zou, H.; Wörner, G. Magmatic longevity of Laacher See volcano (Eifel, Germany) indicated by U-Th dating of intrusive carbonatites. J. Petrol. 2010, 51, 1053-1085. [CrossRef]

19. Frechen, J. Vorgänge der Sanidinit-Bildung im Laacher Seegebiet. Fortschr. Mineral. 1947, 26, 147-166. (In German)

20. Frechen, J. Siebengebirge am Rhein, Laacher Vulkangebiet, Maargebiet der Westeifel. Sammlung geologischer Führer, 3. Auflage; Schweitzerbart: Stuttgart, Germany, 1976; p. 209. (In German)

21. Schmitt, A.K. Laacher See revisited: High-spatial-resolution zircon dating indicates rapid formation of a zoned magma chamber. Geology 2006, 34, 597-600. [CrossRef]

22. Chukanov, N.V.; Krivovichev, S.V.; Pakhomova, A.S.; Pekov, I.V.; Schäfer, C.; Vigasina, M.F.; Van, K.V. Laachite, $(\mathrm{Ca}, \mathrm{Mn})_{2} \mathrm{Zr}_{2} \mathrm{Nb}_{2} \mathrm{TiFeO}_{14}$, a new zirconolite-related mineral from the Eifel volcanic region, Germany. Eur. J. Mineral. 2014, 26, 103-111. [CrossRef]

23. Evsyunin, V.G.; Sapozhnikov, A.N.; Kashaev, A.A.; Rastsvetaeva, R.K. Crystal Structure of Triclinic Lazurite. Crystallogr. Rep. 1997, 42, 938-945. [CrossRef]

24. Rigaku Oxford Diffraction. CrysAlisPro Software System, version 1.171.39.46; Rigaku Oxford Diffraction: Oxford, UK, 2018.

25. Sheldrick, G.M. Crystal structure refinement with SHELXL. Acta Crystallogr. 2015, C71, 3-8.

26. Chukanov, N.V.; Chervonnyi, A.D. Infrared Spectroscopy of Minerals and Related Compounds; Springer: London, UK, 2016; p. 1109. [CrossRef]

27. Clark, R.J.H.; Cobbold, D.G. Characterization of sulfur radical-ions in solutions of alkalipolysulfides in dimethylformamide and hexamethylphosphoramide and in solid-state in ultramarine blue, green, and red. Inorg. Chem. 1978, 17, 3169-3174. [CrossRef]

28. Li, S.; Liu, M.; Sun, L. Preparation of acid-resisting ultramarine blue by novel two-step silica coating process. Indust. Eng. Chem. Res. 2011, 50, 7326-7331. [CrossRef]

29. Chivers, T.; Elder, P.J.W. Ubiquitous trisulfur radical anion: Fundamentals and applications in materials science, electrochemistry, analytical chemistry and geochemistry. Chem. Soc. Rev. 2013, 42, 5996-6005. [CrossRef]

30. Chukanov, N.V. Infrared Spectra of Mineral Species: Extended Library; Springer-Verlag GmbH: Dordrecht, The Netherlands; Heidelberg, Germany; New York, NY, USA; London, UK, 2014; p. 1716. ISBN 9400771274.

31. Buhl, J.-C. Kinetic investigations of the formation of carbonate sodalite. React. Kinet. Catal. Lett. 1992, 48, 641-648. [CrossRef]

32. Balassone, G.; Bellatreccia, F.; Mormone, A.; Biagioni, C.; Pasero, M.; Petti, C.; Mondillo, N.; Fameli, G. Sodalite-group minerals from the Somma-Vesuvius volcanic complex, Italy: A case study of K-feldspar-rich xenoliths. Mineral. Mag. 2012, 76, 191-212. [CrossRef]

33. Armbruster, T.; Schreyer, W.; Hoefs, J. Very high $\mathrm{CO}_{2}$ cordierite from Norwegian Lapland: Mineralogy, petrology, and carbon isotopes. Contrib. Mineral. Petrol. 1982, 81, 262-267. [CrossRef]

34. Sheft, I.; Perkins, A.J. Anhydrous hydrogen fluoride: Raman spectrum of the liquid. J. Inorg. Nucl. Chem. 1976, 38, 665-668. [CrossRef]

35. IMA List of Minerals. Available online: http://cnmnc.main.jp/ (accessed on 16 April 2020).

36. Cámara, F.; Bellatreccia, F.; Della Ventura, G.; Mottana, A. Farneseite, a new mineral of the cancrinite-sodalite group with a 14 layer stacking sequence. Eur. J. Mineral. 2005, 17, 839-846. [CrossRef]

37. Della Ventura, G.; Bellatreccia, F.; Bonaccorsi, E. $\mathrm{CO}_{2}$ molecules in pitiglianoite, a mineral of the cancrinite-sodalite group. Eur. J. Mineral. 2005, 17, 847-851. [CrossRef]

38. Della Ventura, G.; Bellatreccia, F.; Parodi, G.C.; Cámara, F.; Piccinini, M. Single-crystal FTIR and X-ray study of vishnevite, ideally $\left[\mathrm{Na}_{6}\left(\mathrm{SO}_{4}\right)\right]\left[\mathrm{Na}_{2}\left(\mathrm{H}_{2} \mathrm{O}\right)_{2}\right]\left(\mathrm{Si}_{6} \mathrm{Al}_{6} \mathrm{O}_{24}\right)$. Amer. Mineral. 2007, 92, 713-721. [CrossRef]

39. Della Ventura, G.; Bellatreccia, F.; Piccinini, M. Channel $\mathrm{CO}_{2}$ infeldspathoids: A review of existing data and new perspectives. Rend. Accad. Lincei 2008, 19, 141-159. [CrossRef] 
40. Cámara, F.; Bellatreccia, F.; Della Ventura, G.; Gunter, M.E.; Sebactiani, M.; Cavallo, A. Kircherite, a new mineral of the cancrinite-sodalite group with a 36-layer stacking sequence: Occurrence and crystal structure. Am. Mineral. 2012, 97, 1494-1504. [CrossRef]

41. Armbruster, T.; Bloss, F.D. Channel $\mathrm{CO}_{2}$ in cordierites. Nature 1980, 286, 140-141. [CrossRef]

42. Le Breton, N. Infrared investigation of $\mathrm{CO}_{2}$-bearing cordierites. Contrib. Mineral. Petrol. 1989, 103, $387-396$. [CrossRef]

43. Kolesov, B.A.; Geiger, C.A. Cordierite II: The role of $\mathrm{CO}_{2}$ and $\mathrm{H}_{2} \mathrm{O}$. Am. Mineral. 2000, 85, 1265-1274. [CrossRef]

44. Khomenko, V.M.; Langer, K. Carbon oxides in cordierite channels: Determination of $\mathrm{CO}_{2}$ isotopic species and CO by single crystal IR spectroscopy. Am. Mineral. 2005, 90, 1913-1917. [CrossRef]

45. Aines, R.D.; Rossman, G.R. The high temperature behaviour of water and carbon dioxide in cordierite and beryl. Am. Mineral. 1984, 69, 319-327.

46. Charoy, B.; de Donato, P.; Barres, O.; Pintho-Choelo, C. Channel occupancy in an alkali-poor beryl from Serra Blanca (Goias, Brazil): Spectroscopic characterization. Am. Mineral. 1996, 81, 395-403. [CrossRef]

47. Bellatreccia, F.; Della Ventura, G.; Gatta, G.D.; Guidi, M.C.; Harley, S. Carbon dioxide in pollucite, a feldspathoid with the ideal composition $(\mathrm{Cs}, \mathrm{Na})_{16} \mathrm{Al}_{16} \mathrm{Si}_{32} \mathrm{O}_{96} \times \mathrm{nH}_{2} \mathrm{O}$. Mineral. Mag. 2012, 76, 903-911. [CrossRef]

48. Kolesov, B.A.; Geiger, C.A. Molecules in the $\mathrm{SiO}_{2}$-clathrate melanophlogite: A single-crystal Raman study. Am. Mineral. 2003, 88, 1364-1368. [CrossRef]

49. McLaughlan, S.D.; Marshall, D.J. Paramagnetic resonance of sulfur radicals in synthetic sodalites. J. Phys. Chem. 1970, 74, 1359-1363. [CrossRef]

50. Platonov, A.N.; Tarashchan, A.N.; Belichenko, V.P.; Povarennikh, A.S. Spectroscopic study of sulfide sulfur in some framework aluminosilicates. Const. Prop. Miner. 1971, 5, 61-72. (In Russian)

51. Samoilovich, M.I. An ESR study of sulfur-bearing radical ions in minerals. Geokhimiya 1971, 4, 477-483. (In Russian)

52. Clark, R.J.H.; Dines, T.J.; Kurmoo, M. On the nature of the sulphur chromophores in ultramarine blue, green, violet, and pink and of the selenium chromophore in ultramarine selenium: Characterization of radical anions by electronic and resonance Raman spectroscopy and the determination of their excited-state geometries. Inorg. Chem. 1983, 22, 2766-2772.

53. Reinen, D.; Lindner, G.-G. The nature of the chalcogen colour centres in ultramarine-type solids. Chem. Soc. Rev. 1999, 28, 75-84. [CrossRef]

54. Reshetnyak, N.B.; Tretyakova, L.I.; Vokhmentsev, A.Y. Investigation of colour centrums in natural lazurite by means of Raman spectroscopy. Mineral. Zhurnal 1986, 8, 49-60. (In Russian)

55. Tauson, V.L.; Sapozhnikov, A.N. On the nature of lazurite colouring. Zap. Ross. Mineral. Obs. 2003, 132, 102-107. (In Russian)

56. Fleet, M.E. XANES spectroscopy of fulfur in earth minerals. Canad. Mineral. 2005, 43, 1811-1838. [CrossRef]

57. Steudel, R.; Chivers, T. Correction for 'The role of polysulfide dianions and radical anions in the chemical, physical and biological sciences, including sulfur-based batteries'. Chem. Soc. Rev. 2019, 48, 3279-3319. [CrossRef] [PubMed]

58. Tauson, V.L.; Sapozhnikov, A.N.; Shinkareva, S.N.; Lustenberg, E.E. Indicative properties of lazurite as a member of clathrasil mineral family. Dokl. Earth Sci. 2011, 441, 1732-1737. [CrossRef]

(C) 2020 by the authors. Licensee MDPI, Basel, Switzerland. This article is an open access article distributed under the terms and conditions of the Creative Commons Attribution (CC BY) license (http://creativecommons.org/licenses/by/4.0/). 